\title{
Effect of Rainfall Pattern and Crack on the Stability of a Red Bed Slope: A Case Study in Yunnan Province
}

\author{
Zhenping Zhang $\mathbb{D}^{1,2}$ Xiaodong Fu $\mathbb{D}^{1,},{ }^{1,2}$ Qian Sheng $\mathbb{D}^{1,2}$ Dawei Yin $\mathbb{D}^{3},^{3}$ \\ Yongqiang Zhou $\mathbb{D}^{1,2}$ and Juehao Huang $\mathbb{D}^{1,2,4,5}$ \\ ${ }^{1}$ State Key Laboratory of Geomechanics and Geotechnical Engineering, Institute of Rock and Soil Mechanics, \\ Chinese Academy of Sciences, Wuhan 430071, China \\ ${ }^{2}$ School of Engineering Science, University of Chinese Academy of Sciences, Beijing 100049, China \\ ${ }^{3}$ China State Construction International Holdings Limited, Hong Kong 999077, China \\ ${ }^{4}$ Hubei Key Laboratory of Geo-Environmental Engineering, Institute of Rock and Soil Mechanics, Chinese Academy of Sciences, \\ Wuhan 430071, China \\ ${ }^{5}$ State Key Laboratory of Geomechanics and Geotechnical Engineering, Soft Soil Research Center, \\ Ningbo University of Technology, Ningbo 315211, China \\ Correspondence should be addressed to Xiaodong Fu; xdfu@whrsm.ac.cn
}

Received 1 November 2020; Revised 10 December 2020; Accepted 21 December 2020; Published 13 January 2021

Academic Editor: Chong Xu

Copyright (c) 2021 Zhenping Zhang et al. This is an open access article distributed under the Creative Commons Attribution License, which permits unrestricted use, distribution, and reproduction in any medium, provided the original work is properly cited.

Red bed slopes in the southwest of China are associated with a grant number of geological hazards, such as landslides, mud-rock flows, and rock blocks falling, which are vital problems in geotechnical engineering. The damage can be induced or triggered due to a series of human and environmental activities, such as excavation, concentrated or long-term rainfall, earthquake, and fluctuation of groundwater level. According to the field observations and geological exploration results, a small-scale landslide was observed on January 10, 2016, after excavation along XiaoMo highway in Yunnan Province. A numerical model in actual size using GeoStudio software based on this typical red bed engineering slope was established in this study. Back analyses and laboratory tests were used to obtain the mechanical parameters of the geomaterial inside the slope. The historic rainfall data of Mengla County from July to September in 2016 was utilized as the flux boundary in analyzing the seepage variation features and the stability of the engineering slope in the rainy season. One major tension crack was set in the shallow region of the silty clay according to the geology survey to perform the disturbance of excavation on the geomorphology of the slope. Attempts were made to establish the anisotropic permeability of the crack induced by the complex fillings, and differences in the hydraulic response between the cracking and completed slope during the rainfall process were discussed. The result shows that the factor of safety of the slope without crack before the rainfall is 1.076, and the slope is considered in the state of the critical limit equilibrium, which is in accordance with the previous state of the slope under real conditions. The pore water pressure variations of the monitor points in the shallow region of the completed slope present close compliance with the rainfall intensity subjected to different rainfall patterns, which also controls the distribution of the plastic zone in the slope after rainfall. The comparisons in the seepage field and plastic zone between the cracking and completed slope reveal that the crack can shorten the infiltration path effectively, and the higher the permeability coefficient in the vertical direction is, the larger the pore water pressure increasing zone is and the higher the underground water level is, which should be paid more attention in highway constructions.

\section{Introduction}

The term "red beds" refers to the special detrital sedimentary red or reddish-brown rock masses due to the ferric oxide compound inside. The earliest descriptions of red beds in the geological data are related to Coronation Geosyncline and Athapuscow aulacogen in western Canada [1]. It is convinced by the early researchers that the occurrence of red 
beds was the direct result of arid paleoclimate, mostly distributed in the desert, and could be formed at subsurface conditions [2]. So far, general continental red beds have been found in various environments and climatic settings, such as the upper Cretaceous oceanic red beds in the North Alps and southern Tethyan Himalaya of Southern Tibet [3, 4] and Cretaceous red beds in Sichuan Basin and Southwest Japan $[5,6]$.

In China, red beds are widely distributed in the southeast, southwest, and northwest area, covering approximately $9.5 \%$ of China, and $83 \%$ of these lands are distributed in the humid region, which makes it an important part of research on the red bed slope stability during rainfall [7]. Red beds are widespread in the central and western parts of Yunnan Province as a geohazards-prone rock formation. As the major components of the red bed area, the siltstone and mudstone formed in different ages are typical clay-bearing rocks, which are highly susceptible to disintegration and crumble when exposed to moisture varying $[8,9]$. A lot of studies have presented the softening effect of the increasing water content on the mechanical characteristics of the soft rock based on laboratory tests and numerical simulations [10-12]. Therefore, long-term rainfall and strong weathering turn the clay-bearing rock in the red bed area into clastic rocks in different sizes mixed up with the residual soil. The particle diameter of the strongly weathered rock clasts ranges from a few to tens of centimeters, and the random spatial positions of the rock masses often create several large pores, which leads to the loose structure of the natural material in the shallow region of the red bed area. The differences in the strength and stiffness between the two compositions result in that the vertical tension cracks are common to be observed during or after the disturbances in the shallow red bed area $[13,14]$. The crack provides a fast movement path for rainfall into the slope and the slope failure in the red bed area is prone to occur during rainy seasons, representing persistent threats to human settlements and infrastructures $[15,16]$. However, it is noteworthy that the crack in the shallow region generally shows rough and tortuous with soil or small size stone clasts filled in the crack, which results in anisotropic permeability of the crack. Therefore, it is necessary to consider the anisotropic feature in the permeability of the crack in analyzing the cracking slope failure mechanism subjected to rainfall.

Landslide prediction in the red bed area is a necessary task during the engineering construction programs. Rainfall acts as one of the important triggering factors for the slope failure, and the failure mechanism of the rainfall-induced landslide has been studied in depth [17-19]. The concentrated rainfall usually leads to sudden variations in the pore water pressure and groundwater level, which constitute the trigger of the typical landslide. The influence of rainfall on the slope stability is significant, especially on the bedding slope. Because the potential sliding surface of the bedding slope is common to be located in the relatively soft surface or intercalation surface, the rainfall infiltration plays a role in reducing the strength of the layer of the material and the rock or soil inside the slope is easy to move downwards along the soft layer surface under gravity.
Many studies analyze the influence of rainfall on slope stability, and two main methods are utilized: (1) field investigations and monitoring data analysis through model tests [20-23] and (2) numerical simulations, such as the finite element method and finite difference method [24-28]. Numerical simulation has advantages in obtaining some key physical quantities, which are difficult to measure in the model tests and field investigations. In addition to several numerical simulation methods, the limit equilibrium method has been promoted to analyze the failure mechanisms of rainfall-induced red bed landslides. The factor of safety of the potential sliding surface inside the slope is the most common index to assess slope stability. The calculation often relies on the limit equilibrium model, which builds on the assumption that the slope consists of rigid materials and that possible destruction occurs along the potential sliding surface over a large number of the randomly selected sliding surfaces. However, the stress distributions obtained from the traditional limit equilibrium formulations are not necessarily representative of the actual field stress. The limit equilibrium method has received considerable attention for two-dimensional [29-31] and three-dimensional [32-34] slope assessments combined with algorithm and geographic information system. Zheng [35] presents a work based on the combination of the limit equilibrium model with the genetic algorithm method for predicting the factor of safety and failure surfaces of rock slopes subject to flexural toppling failure. Jia et al. [36] propose a spatiotemporal approach for analyzing rainfall-induced slope stability, coupling a rainfall infiltration model, and three-dimensional limit equilibrium methods within the geographic information system.

Recently, the numerical simulations based on the finite element stress to calculate the factor of safety have been proved to be effective in looking for the position of potential slip surface and judging the slope stability [37-40]. The approximate location of the potential failure surface in the slope could be set in advance, and the sliding body is divided into finite vertical slices, and stress of the mid-point of the slice base is collected to obtain the factor of safety [41]. The difficulty in the calculation of the negative pore water pressure in the traditional limit equilibrium method is solved based on the finite element method in seepage calculation. At the same time, the results of the seepage field could be put into the volumetric deformation calculation to obtain the plastic zone and deformation of the slope during the rainfall.

A better understanding of the evolution mechanisms of the landslide is important to predict the occurrences of landslides and suggest remediation measures based on the failure mechanisms and deformation characteristics. Up to now, most studies focused on the influence of rainfall amount (rainfall threshold), rainfall intensity, and duration on the slope stability. However, the rainfall pattern as one of the major features of the rainfall event should not be neglected in analyzing rainfall-related slope stability. Rainfall pattern reflects the rainfall intensity over time, which controls the flux condition at the ground surface and affects the slope stable state. Although many researchers have realized the important role played by rainfall patterns 
in slope stability assessment, the rainfall pattern is always simplified as a uniform type or a time-related linear distribution due to loss of rainfall monitor data. In reality, the rainfall intensity shows random fluctuations over the whole rainfall process, which may not be classified as one typical rainfall pattern. In this study, the statistical information of historical data from July to September in 2016 is utilized to analyze the red bed slope stability under different rainfall patterns to characterize and restore the real natural condition.

The objective of this study is to investigate the red bed slope stability considering the rainfall patterns and anisotropic permeability of crack based on a real engineering slope located in the red bed area in Yunnan Province. The measured rainfall data collected from the meteorological data station in Mengla County from July to September in 2016 were selected as the target rainfall patterns to simulate the influence of real rainfall patterns on the red bed slope. The tensile crack with anisotropic permeability was taken into account and the historical rainfall data of August were adopted to perform the influence of crack on the seepage field and plastic zone. Meanwhile, the variation laws of the factor of safety of the cracking and completed slope under the same rainfall condition were introduced to analyze the influence of anisotropic permeability of the crack on the slope stability.

\section{Study Area and Site Conditions}

The highway from Xiaomengyang to Mohan (XiaoMo highway) is one of the vital parts of the Asian highway network planning, which connects China and other ASEAN countries. The medium-to-thick-bedded mudstone clasts are commonly found to be exposed in the slope along the highway (Figure 1). Most of the totally strongly weathered slopes are terrestrial lacustrine deposits. The fine-grained argillaceous rock formed under the relative static water condition is turned into the inclined red bed slope with several tectonic joints after tectonic movement.

The study area is a typical red bed slope along the XiaoMo highway located in Xishuangbanna, Yunnan Province. The geographic coordinates are longitude $101^{\circ} 07^{\prime}$ and latitude $21^{\circ} 12^{\prime}$ as shown in Figure 2. The initial slope was located on the right side of the highway, and the route was passed through in the form of the excavation cutting. A small-scale landslide occurred on January 10, 2016, after stage excavation, and several tension cracks were observed outside the groove line. The collapsed area is approximately $100 \mathrm{~m}$ long and the estimated total volume of collapsed mass is around 700 thousand $\mathrm{m}^{3}$. Considering the relatively long rainy season in Yunnan Province, the rainfall and crack would pose a great threat to the highway slope. The stability of the slope along the highway is vital considering the safety of highway use and construction. Therefore, it is necessary to focus on the influence of the rainfall patterns and crack on the deformation and failure mechanisms and the stability of the engineering slope.

Figure 3(a) shows the engineering geology planar of the landslide and surface conditions, and the results show that the surface of the slope is dominantly covered by the silty clay and strongly weathered silty mudstone. Figure 3(b) shows the profile of the studied slope and the locations of site boreholes, and borehole samples are used to obtain the physical and mechanical properties of the geomaterial inside the slope. The lithology comprises the medium-to-thicklayered silty and argillaceous mudstone showing close contact with the underlying bedrock. The drilling results show that the coarse-grained mudstone clast is commonly mixed with residual soil in the layer of argillaceous mudstone.

The climate in the study region is characterized as the seasonal tropical monsoon climate with a typical rainfall period. Figure 4(a) shows the daily rainfall distributions from May to October based on the measured data from the meteorological monitor station in Mengla, and JulySeptember is considered as the concentrated rainfall period. The daily rainfalls of July, August, and September are presented in Figures 4(b)-4(c). The 22 days in July were monitored as the effective rainy days, which means the daily rainfall is more than $0 \mathrm{~mm}$, and the max daily rainfall occurred on July 14, 2016. The rainfall pattern is similar to the single-peak type viewed from the whole month, as the rainfall intensity increases first and then decreases. The daily rainfall in August is shown to be more complex than that in July. The effective rainy day is 24 , and the maximum continuum rainy day is 10 from August 7 to August 16. There is about nine days' rainfall amount more than $15 \mathrm{~mm}$ and the distribution of rainfall is relatively scattered, which could be classified as the wave-type rainfall. The daily rainfall in September is much smaller than the one in July and August, and there are only 14 effective rainy days. The differences in the daily rainfall in each rainfall event are not significant. Therefore, the rainfall pattern of September could be considered as the uniform type. The effect of the rainfall pattern on the seepage and stress field of the completed slope is discussed based on the real historic data of July, August, and September in 2016. From the discussions about the daily rainfall above, the rainfall patterns of July, August, and September could be considered as the three types of rainfall pattern: single-peak, wave, and uniform type, respectively.

\section{Data and Method}

3.1. Materials and Tests. Preliminary exploration results in Figure 3(b) show that the thickness of the $4.5 \mathrm{~m}$ reddishbrown silty clay layer is distributed on the surface of the slope, and the strongly weathered silty mudstone, softening argillaceous mudstone, and bedrock are found from the surface to the bottom. The grading characteristic curve of the collected samples of the strongly weathered silty mudstone is shown in Figure 5. The maximum diameter is about $10 \mathrm{~mm}$, and the material is mainly composed of the fine grain (sand and silt) (80\%) and gravel (20\%). The natural moisture content was obtained through the field moisture test as $7.3 \%$, and the saturated moisture content was $22.01 \%$ based on the laboratory results. In order to avoid the scale effect and boundary effect of the gravel particle on the accuracy of mechanical laboratory test results, the large-scale triaxial 

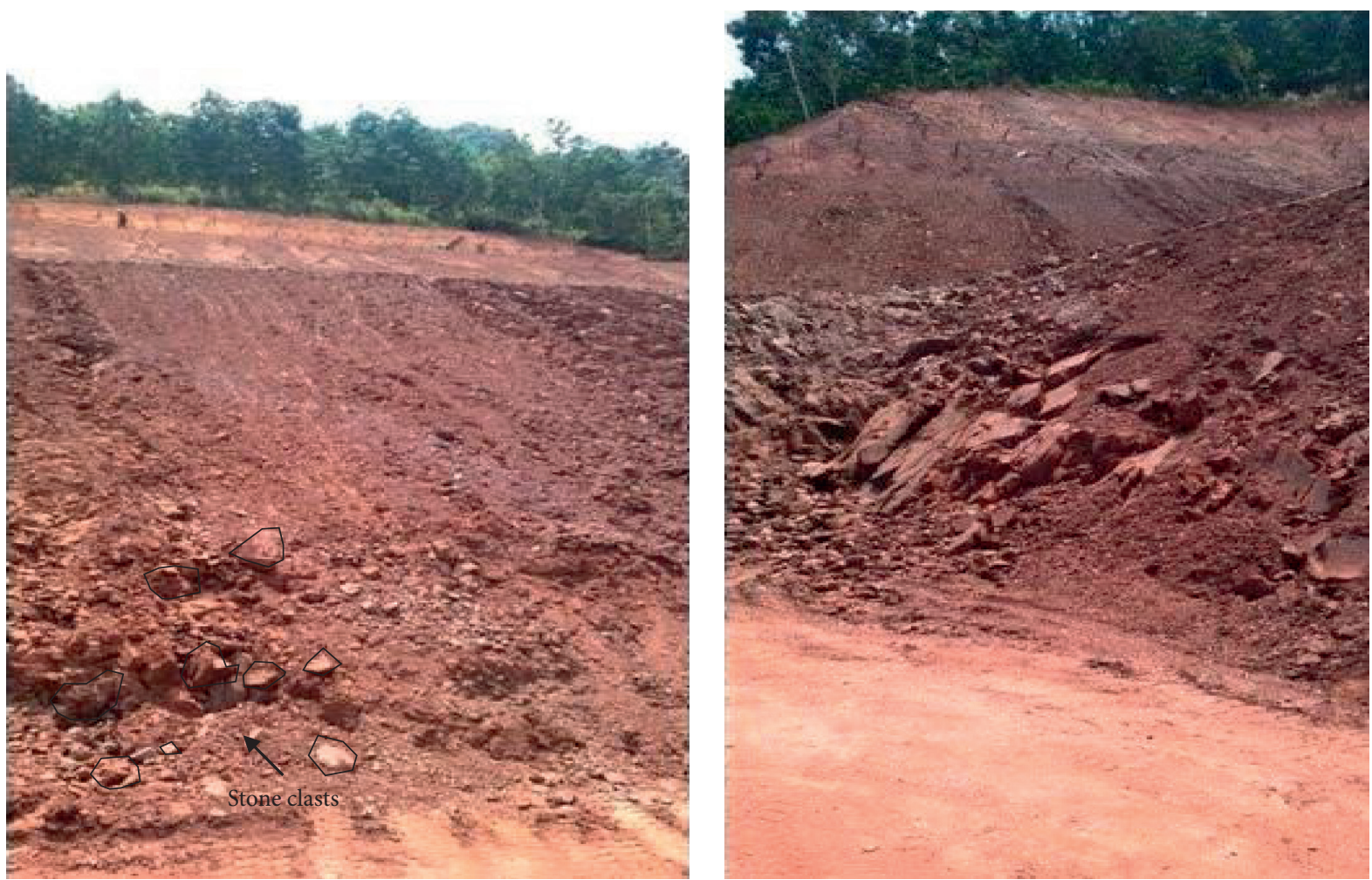

Figure 1: Surface of the highway slope along XiaoMo highway in Yunnan Province.

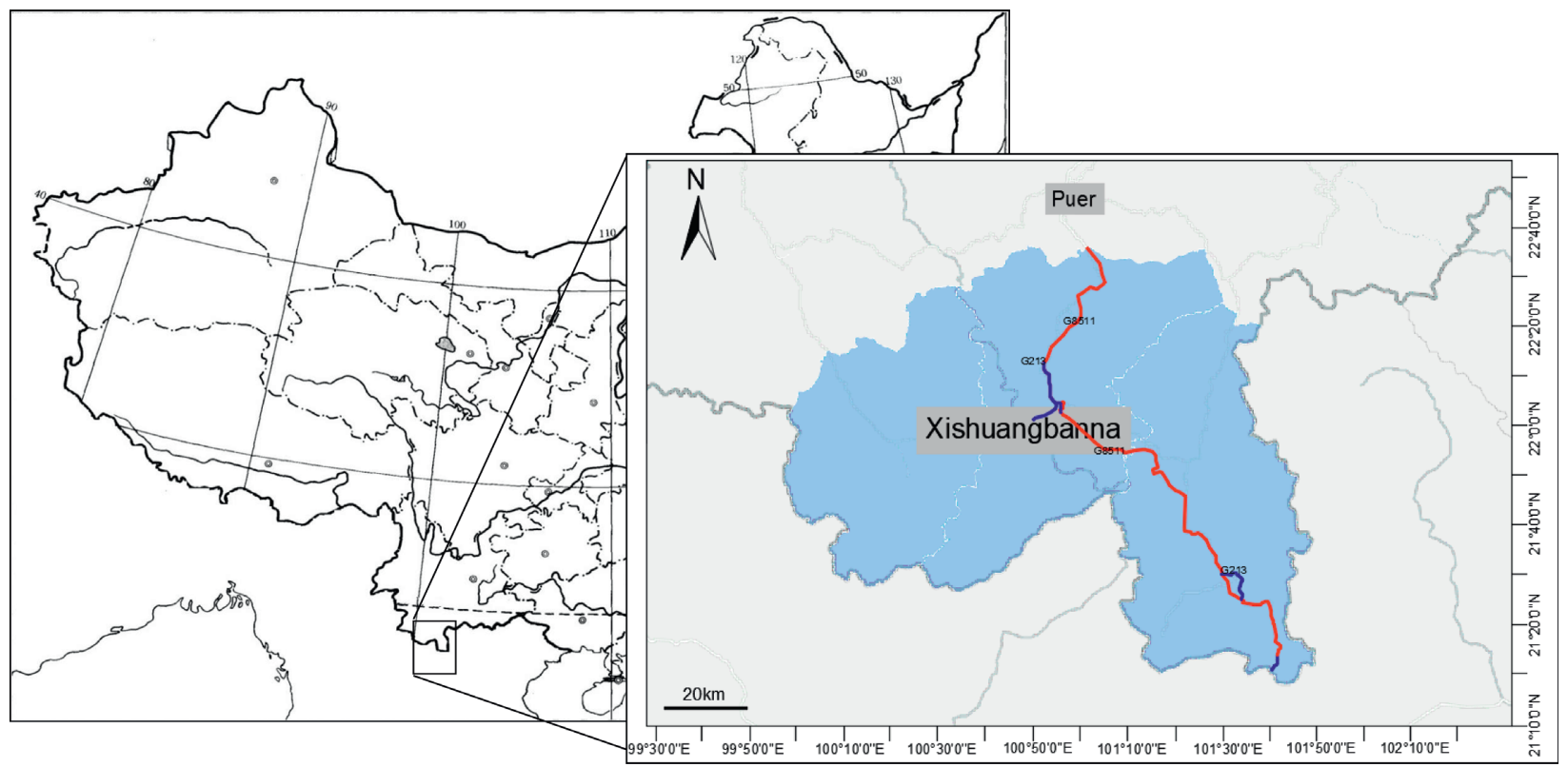

Figure 2: Site location of the XiaoMo highway.

apparatus was selected to obtain the shear strength parameters. The results are shown in Table 1.

3.2. Parameter Back Analysis. Figure 3(b) shows that there is a layer of argillaceous mudstone which was below the groundwater level in the long term. The water softening effect changes the mudstone into soft plastic soil mixed with rock clasts. The geology exploration borehole results show that the softening argillaceous mudstone layer contains several rock fragments for large scale. Therefore, the argillaceous mudstone samples collected from the field may not 


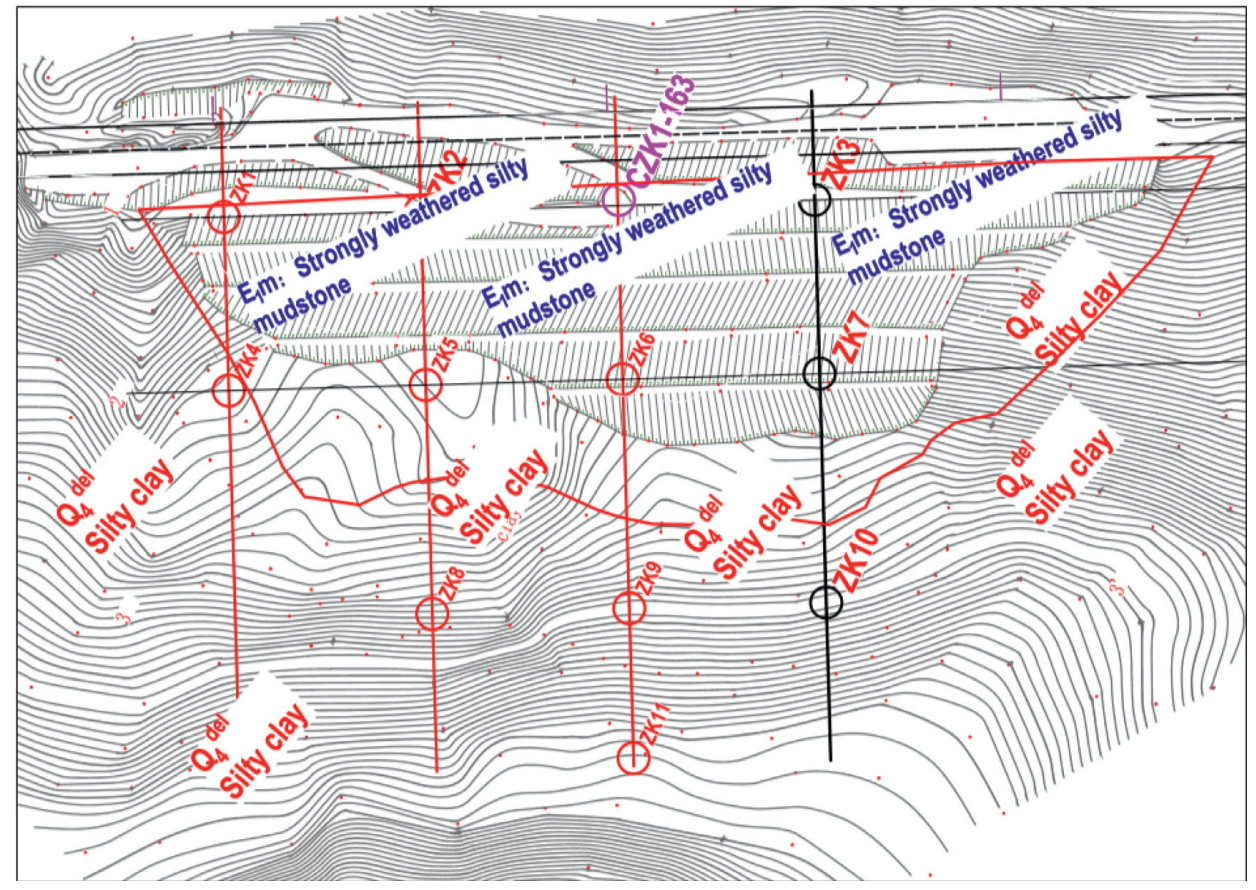

(a)
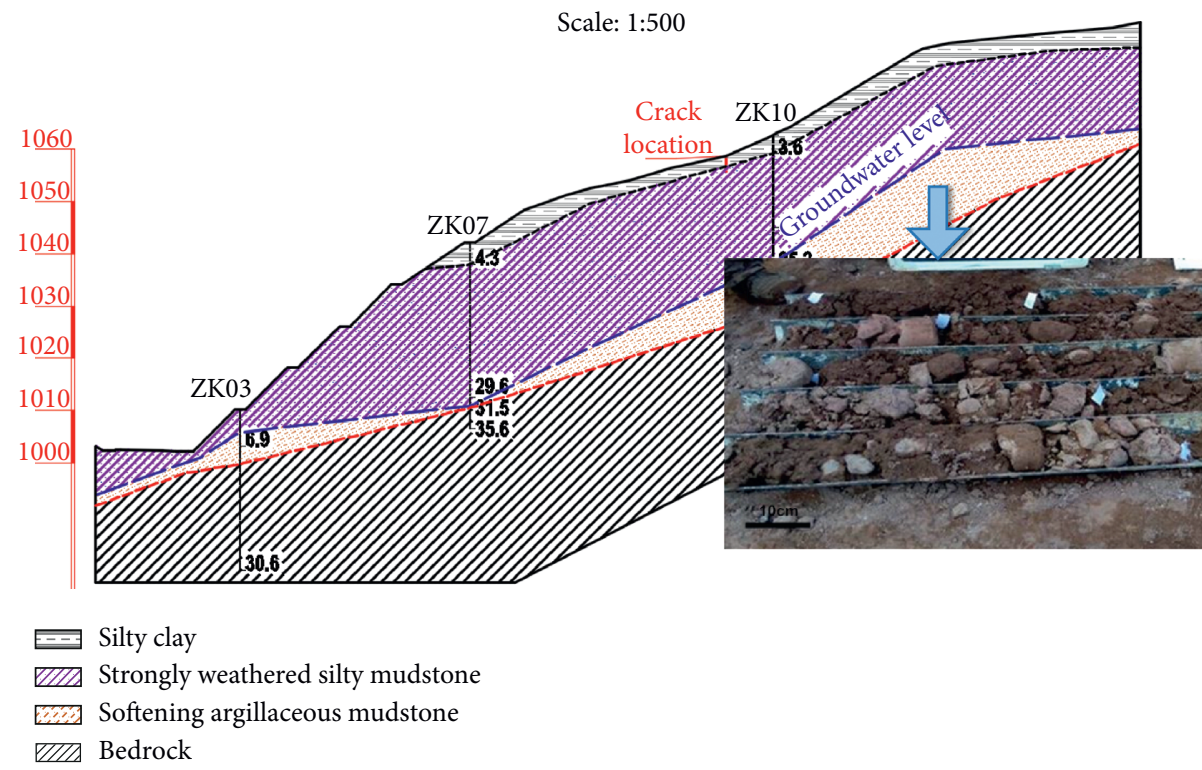

(b)

Figure 3: The (a) planar graph; and (b) cross-sectional profile of the studied slope.

cover the completed particle grading of the natural material and the limitations of the mechanical laboratory tests of the material with large-scale particles should be noted.

In order to obtain the more accurate shear strength parameters of this layer, the parameter back analysis was performed. The back analyses with test data, monitoring data, and field observations have played an important role in geotechnical techniques and the accuracy has been proved by several researchers [42-44]. Recently, spatial variability of the soil properties has been taken into account in the probabilistic back analyses to improve the facticity of the results. The parameter back analysis in this study is performed based on several groups of parameter trial calculations due to the limited monitoring data. In this paper, laboratory test results of strongly weathered silty mudstone were used as the initial values of the geomaterial parameters. Considering the water softening effect and excavation disturbance on the mudstone under the groundwater level, the strength parameters of the argillaceous mudstone were reduced. According to the relationship between the factor of safety of the potential sliding surface and the development stage of the landslide based on field observation, the suitable 


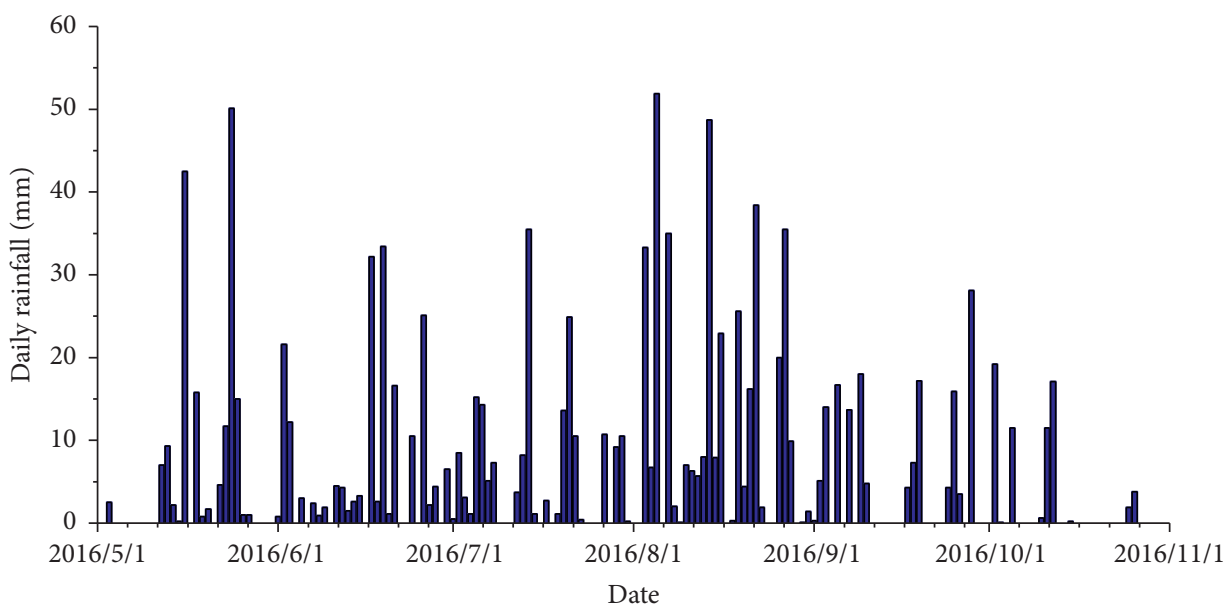

(a)

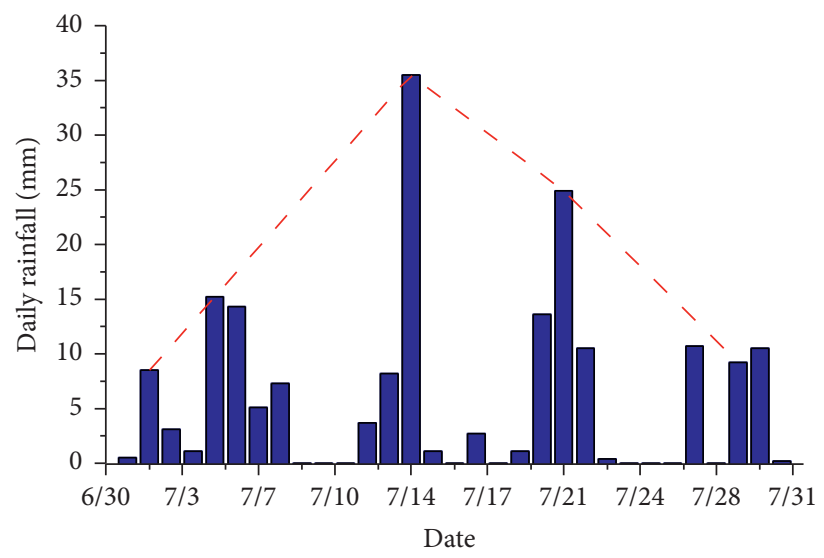

(b)

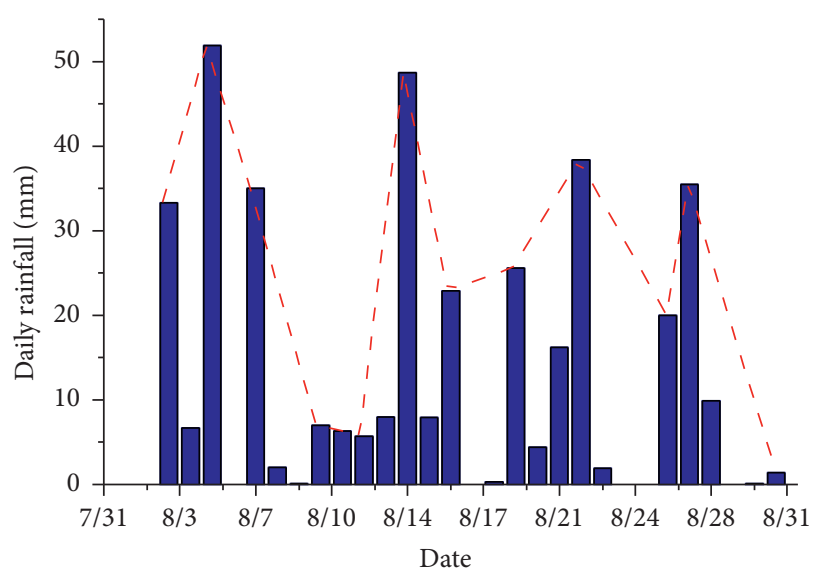

(c)

Figure 4: Continued. 


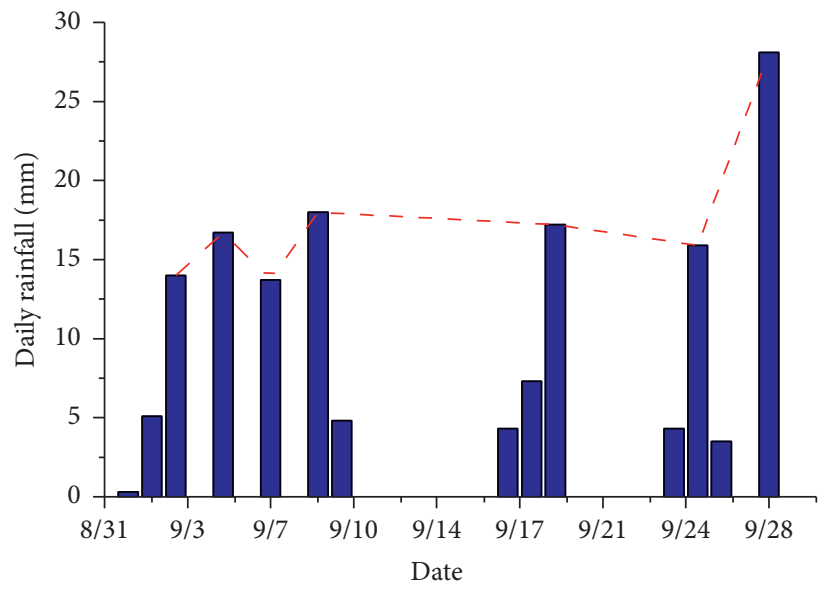

(d)

Figure 4: The daily distribuition (a) from May to October; (b) in July; (c) in August; (d) in September in Mengla county.

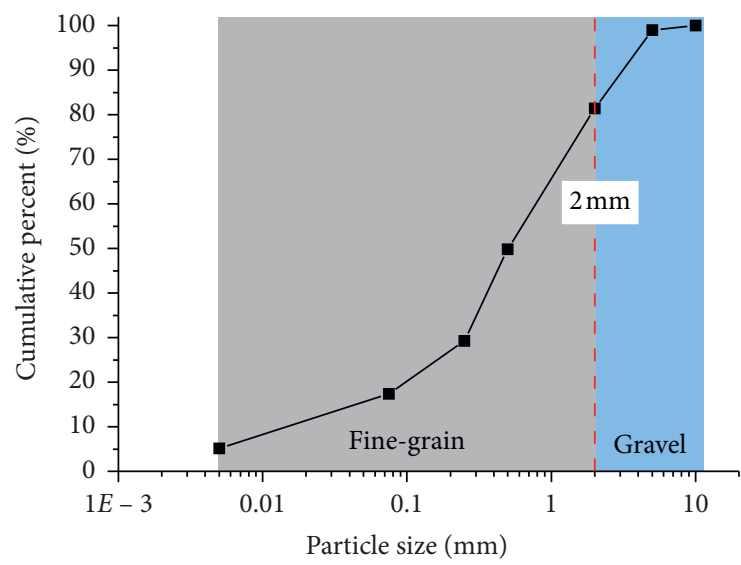

FIGURE 5: Grading curve of the strongly weathered silty mudstone samples.

TABLE 1: Material parameters.

\begin{tabular}{|c|c|c|c|c|c|c|c|}
\hline Material & $\begin{array}{l}\text { Dry density } \\
\left(\mathrm{g} / \mathrm{cm}^{3}\right)\end{array}$ & $\begin{array}{c}\text { Effective } \\
\text { cohesion } \\
(\mathrm{kPa})\end{array}$ & $\begin{array}{c}\text { Effect } \\
\text { friction } \\
\text { angle }\left(^{\circ}\right)\end{array}$ & $\begin{array}{c}\text { Saturated } \\
\text { permeability } \\
\text { coefficient }(\mathrm{m} / \mathrm{d})\end{array}$ & $\begin{array}{l}\text { Saturated water } \\
\text { content }(\%)\end{array}$ & $\begin{array}{l}\text { Effective E- } \\
\text { modulus } \\
(\mathrm{MPa}) \\
\end{array}$ & $\begin{array}{l}\text { Poisson's } \\
\text { ratio }\end{array}$ \\
\hline Silty clay & 1.8 & 26 & 20 & 0.03 & 33.4 & 18 & 0.27 \\
\hline $\begin{array}{l}\text { Strongly weathered } \\
\text { silty mudstone }\end{array}$ & 2.1 & 24.5 & 21.5 & 0.8 & 22.0 & 328 & 0.26 \\
\hline $\begin{array}{l}\text { Softening } \\
\text { argillaceous } \\
\text { mudstone }\end{array}$ & 2.0 & 21.5 & 19.4 & 0.08 & 25.2 & 558 & 0.26 \\
\hline Bedrock & 2.45 & 200 & 35 & $8.64 e-3$ & 7.5 & 970 & 0.25 \\
\hline Tension crack & - & - & - & 35.8 & $1 e-3$ & $1 e-3$ & 0.49 \\
\hline
\end{tabular}

shear strength of the softening argillaceous mudstone could be determined after several trial calculations. The results are shown in Table 1.

3.3. Methodology. Slope stability analysis of the red bed slope in this study is performed utilizing the GeoStudio software and the models of SIGMA, SEEP/W, and SLOPE/W are coupled to assess the slope stability during the rainfall. During the rainfall, the variation in pore water pressure changes the geomaterial inside the slope by physical, chemical, and mechanical effects, which leads to the change in the stress field. At the same time, the varying stress distribution changes the void's structure and permeability of the material. Therefore, the interaction between seepage and stress in the soil and rock system is noteworthy in analyzing 
the rainfall-induced landslide mechanisms. Sometimes, instead of solving two sets of equations at the same time in the coupled analysis, it is numerically advantageous to solve the SEEP/W transient flow equations first and then use the results in the coupled equations as known hydraulic boundary conditions. The results of the coupled and uncoupled analysis are similar, and the uncoupled analysis shows great advantages in the complex calculation conditions. For the simulation under rainfall, the results of the steady seepage are applied in the SEEP/W for the transient seepage and the pore water pressure was reentered into SIGMA model for the coupled stress-pore water pressure analysis.

The stress distribution in the traditional limit equilibrium method may not represent the actual stress field due to the limitations of the inherent concepts and assumptions. The relationship between stress and strain has to be added to the stability analysis to overcome the limitations. In this study, the stress distributions of the slope during the whole rainfall process were calculated first in the SIGMA model, and the factor of safety was obtained based on the stresses using the SLOPE/W model. The factor of safety determined based on the finite element stress-based method is calculated as the ratio of the sum of the total available shear stress resistance to the sum of the mobilized shear along the entire length of the slip surface. The soil system in the unsaturated state has three phases, soil phase, liquid phase, and gas phase, and only one single stress variable might not be appropriate for its explanation. In this paper, the unsaturated shear strength equation by extended Mohr-Coulomb criterion is utilized as follows [45]:

$$
\tau=c^{\prime}+\left(\sigma-u_{a}\right) \tan \varphi^{\prime}+\left(u_{a}-u_{w}\right) \tan \varphi^{b},
$$

where $\tau$ is the shear strength at failure; $c$ is the effective cohesion; $\sigma-u_{w}$ is the effective normal stress on the plane at failure; $u_{a}-u_{w}$ is the matric suction, as the negative pore water pressure, and $\varphi^{\prime}$ is the effective angle of internal friction; $u_{a}$ is the air pressure; $\varphi^{b}$ is the effective friction angle related to matric suction. According to equation (1), matric suction (negative pore water pressure) variation due to rainfall infiltration has an important impact on the strength of unsaturated material. Therefore, the unsaturated slope stability usually shows a dynamic trend during the rainfall due to the various water content and pore water pressure.

\section{Modeling}

A generalization model for the red bed slope was completed based on the borehole results and geologic section as shown in Figure 6. The slope model is approximately $103.6 \mathrm{~m}$ in height and $220 \mathrm{~m}$ in width. The global element size is $1.0 \mathrm{~m}$, and the entire profile is divided into 11861 nodes and 11707 quadrilateral-triangular elements. Based on the laboratory test and back analysis results, the mechanical parameters of the geomaterial inside the slope are given in Table 1 .

Compared with the saturated seepage analysis, the water content and permeability coefficient changing with the pore water pressure are the particular functions in the unsaturated seepage calculation. The soil-water characteristic curve (SWCC) is a key function to describe the relationship between pore water pressure and water content. Although many researchers have obtained the SWCC through laboratory tests, there is a large limitation in the determination range and the measurement process requires time. The SEEP model in GeoStudio software provides available methods to build the volumetric water content function based on the grain size, saturated water content, and material property.

The permeability of the unsaturated geomaterial shows a close relationship with the pore water pressure, and the flow of water becomes much easier following the suction decrease because of the increased area and decreased tortuosity in the water phase. The hydraulic conductivity function obtained from the laboratory measurements often takes a very long time due to the low conductivity values that can be present in the saturated soil. The diameter of the clastic mudstone in the strongly weathered mudstone makes demands on the size of the test apparatus. Therefore, we use the model provided by SEEP to predict unsaturated hydraulic conductivity function with the saturated permeability measured through the tests. Figure 7 presents the SWCC and permeability coefficient curves of all the geomaterials inside the slope for the unsaturated calculation.

A large number of studies have attempted to simulate the preexisting cracks and one of the common methods is to determine the special crack element as the empty or solid element, which is convenient to analyze the crack propagation with known depth and position [46-48]. In this study, a major crack was observed as the landslide occurs after excavation with $0.35 \mathrm{~m}$ width and $3 \mathrm{~m}$ depth according to the geological survey. The position and geometric sizes are applicable in numerical simulation, and the cracking slope model is shown in Figure 6. The crack is set as a rectangular region with a mesh size of $0.1 \mathrm{~m}$. The crack is easy to be filled with water during the actual rainfall process, especially in the concentrated and strong rainstorm. In this study, the top interface of the crack region is considered in the saturated state during the effective rainy days to analyze the impact of the extreme rainfall situation on the slope stability.

The discussions about the crack are concentrated on the influence of the crack with anisotropic permeability on the slope stability. The permeability coefficient ratio is introduced to describe the anisotropic hydraulic conductivity of a crack, and it is expressed by

$$
\eta=\frac{k_{y}}{k_{x}},
$$

where $\eta$ is the permeability ratio; $k_{x}$ and $k_{y}$ are the saturated hydraulic conductivities of the crack in the normal and tangential directions, respectively. The saturated permeability coefficient in the normal direction of the crack is shown in Table 1 , and three permeability ratios $(\eta=0.1,1$, and 10) of the crack are considered. The permeability ratio of 0.1 means that the saturated tangential permeability is smaller than the one in the normal direction, which represents that the crack is still filled with rock clasts and 


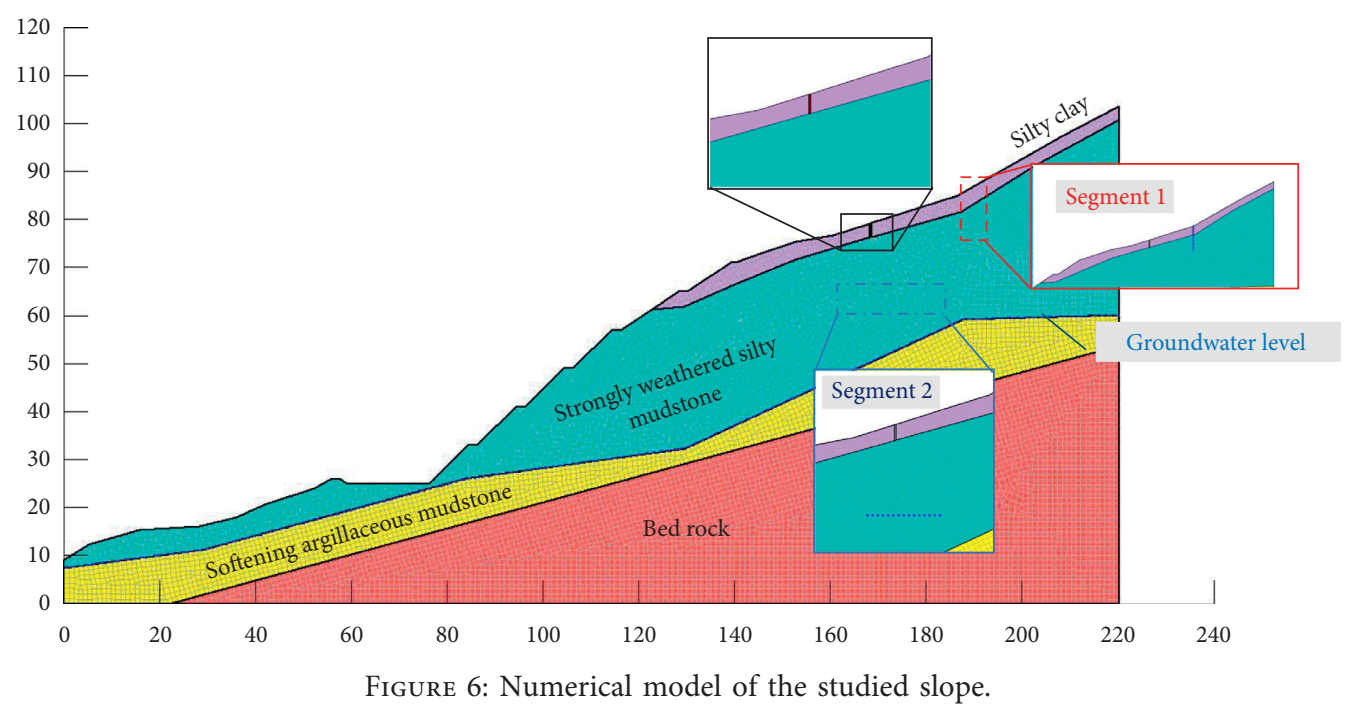

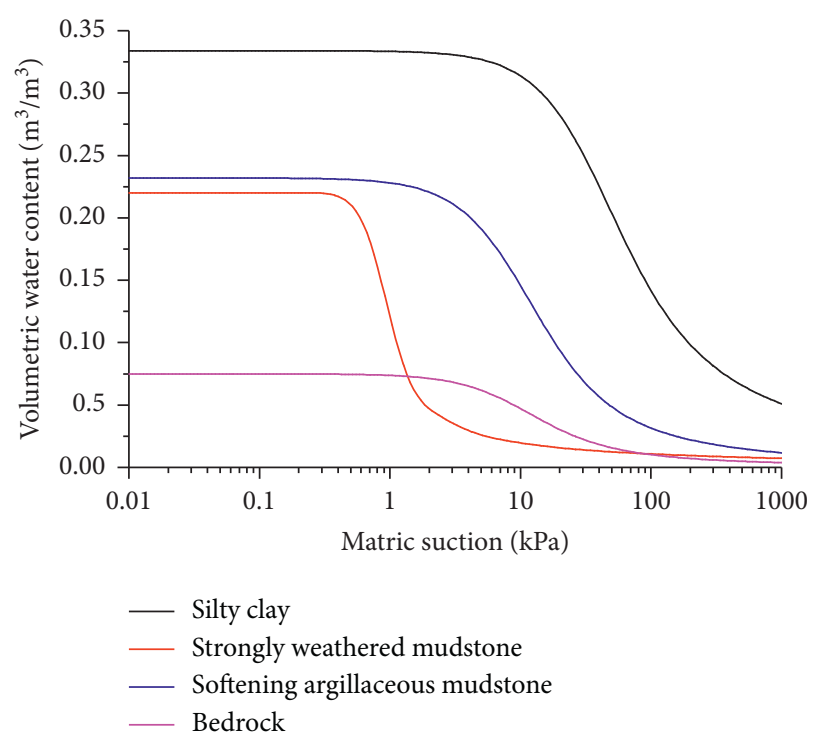

(a)

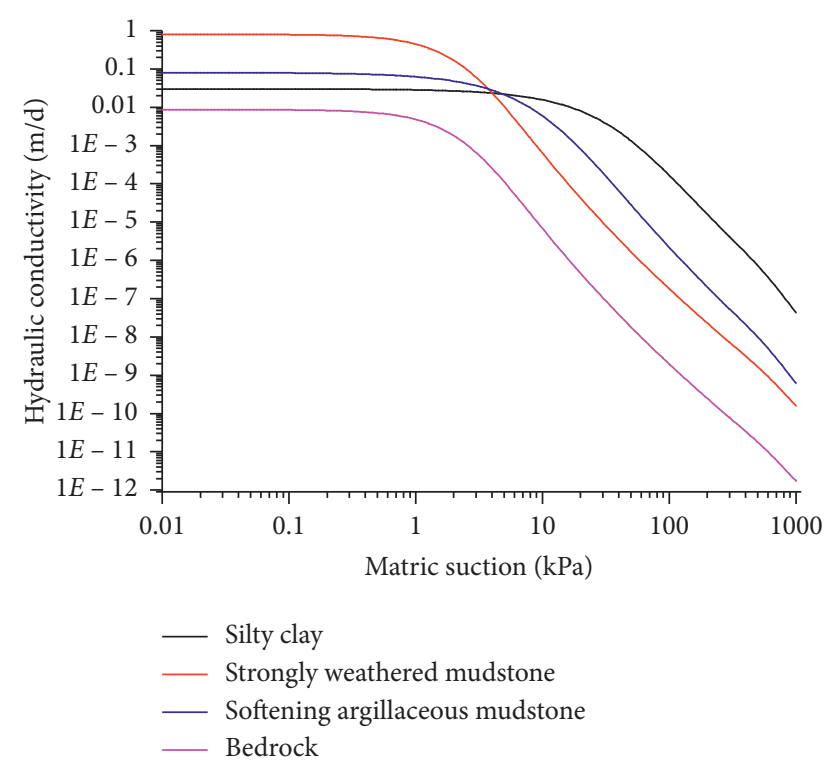

(b)

Figure 7: The curve of (a) volumetric water content; (b) hydraulic conductivity and matric suction.

downward infiltration is blocked. The permeability ratio of 1.0 can be considered as a special case where the saturated permeability of the crack is isotropic. This case is suitable to describe that the filling inside the crack is residual soil or other homogeneous materials. The permeability ratio of 10 means that the saturated tangential permeability coefficient is considerable, which can be supposed to the situation where there are no fillings inside the crack and the rainfall could reach the bottom of the crack in a short time since the rainfall starts.

For the seepage analysis, the initial groundwater table is set according to the information on the cross-sectional profile of the slope. The downward vertical influx is on the slope surface based on the rainfall statistics above. Surface runoff is permitted when the developed pore water pressure on the surface gets to a positive value. An automatically adjusted time-step increment is selected for attaining convergence.

\section{Results and Discussion}

5.1. Effect of Rainfall Patterns on the Slope Stability without Crack. Figure 8 shows the pore water pressure contour and plastic zone distribution of the slope without the crack (the completed slope) before rainfall. The potential sliding surface of the slope without crack before the rainfall could be found in Figure 8(a), and the factor of safety is 1.076. In the numerical analyses, the geomaterials inside the slope are considered as the homogeneous and continuous medium to increase the accuracy and convenience of the numerical 

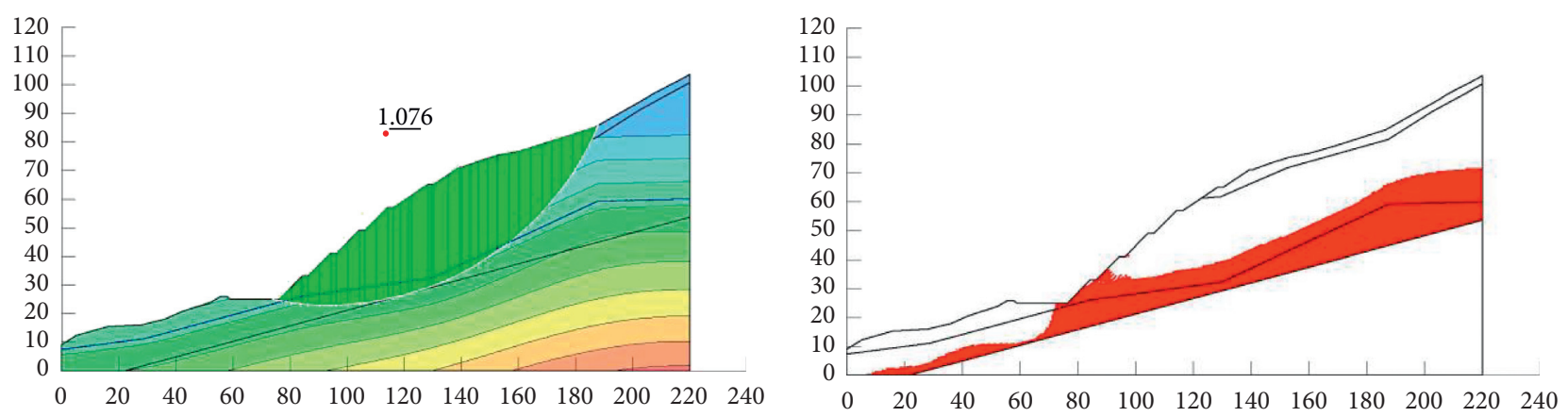

$\begin{array}{ll}\text { Pore-water pressure } & \\ \square-300 \text { to }-220 \mathrm{kPa} & \square 180 \text { to } 260 \mathrm{kPa} \\ \square-220 \text { to }-140 \mathrm{kPa} & \text { } 260 \text { to } 340 \mathrm{kPa} \\ \square-140 \text { to }-60 \mathrm{kPa} & \square 340 \text { to } 420 \mathrm{kPa} \\ \square-60 \text { to } 20 \mathrm{kPa} & \square 420 \text { to } 500 \mathrm{kPa} \\ \square 20 \text { to } 100 \mathrm{kPa} & \square 500 \text { to } 580 \mathrm{kPa} \\ \square-100 \text { to } 180 \mathrm{kPa} & \end{array}$

(a) (b)

Figure 8: (a) Pore water pressure contour; (b) plastic zone distribution of the completed slope before rainfall.

calculation. The potential sliding surface is obtained after several times of iterations and the shape is shown in Figure 8(a) as a circular arc sliding surface. According to the Specifications for Design of Highway Subgrades (JTG D302004), the range of the factor of safety of the potential sliding surface in the slope in the critical stable state is set as 1.0 1.1. The value of the factor of safety of the potential sliding surface based on the numerical calculation is close to 1.0, which means that the state of the red bed slope is close to the limit equilibrium state according to the specification. Due to a lack of the monitor data of slope deformation, the slope stability state is considered to be used to testify the results of the numerical simulations based on the mechanical parameters obtained from laboratory tests. According to the field observations, the slope failure has occurred after excavation and the tension crack was observed in the middle part of the slope, which is in agreement with the critical state in the numerical result.

The plastic zone distribution is shown in Figure 8(b), which shows that the middle and back regions of the softening argillaceous mudstone have been into the yield stage under the initial condition, caused by the low strength parameters under the long-term water softening effect. Besides, the weathered silty mudstone near the bottom of the excavation region has been covered with the plastic zone, which is attributed to the uploading and stress redistribution inside the slope due to the excavation. The position of the potential sliding surface in Figure 8(a) almost covers the middle part of the plastic zone in the layer of the argillaceous mudstone, which means that the soft interlayer has a controlling effect on the destruction region and form of the slope.

The effect of rainfall patterns on the slope seepage is discussed based on the pore water pressure distributions of the monitor points in segment 1 , which are located near the entry of the potential sliding surface in the shallow region of the slope. Figure 9 shows the pore water pressure distributions of the points at different heights during the rainfall duration. In order to make the variations much clearer, the data points with an obvious increase compared with the initial state $(t=0 \mathrm{~d})$ were marked as the hollow points. The results in Figure 9 show that the pore water pressure of the points of which the height is higher than $81.975 \mathrm{~m}$ shows the response to the rainfall, and the response laws of the pore water pressure of the monitor points located on the surface $(H=84.975 \mathrm{~m})$ are similar to the daily rainfall variations. Take the pore water pressure of the slope under the wavetype (in August) rainfall in Figure 9(b) as an example. The pore water pressure of the point at $84.975 \mathrm{~m}$ (marked as the black hollow square) presents two obvious increases on the $3 \mathrm{rd}$, 5th, and 14th days and several small waves could also be observed, which is in agreement with the daily rainfall variation in August. The pore water pressure of the point at the surface under three rainfall patterns increases to a stable status after a period of rainfall. The whole rainfall in August is about $389.2 \mathrm{~mm}$, which is much larger than $187.4 \mathrm{~mm}$ in July and $153.2 \mathrm{~mm}$ in September. Therefore, the final value of pore water pressure in Figure 9(b) is near $-26.67 \mathrm{kPa}$, while the final values at the end of July and September in Figures 9(a) and 9(c) are near $-38 \mathrm{kPa}$. The variations of the points located at $81.975 \mathrm{~m}-83.975 \mathrm{~m}$ inside the slope all present the different degrees of increase after rainfall subjected to the various rainfall patterns. The value of pore water pressure of the point at $83.975 \mathrm{~m}$ presents an obvious increase from $-250 \mathrm{kPa}$ to $-25 \mathrm{kPa}$ after $22 \mathrm{~d}$ wavetype rainfall, while the values of the point at the same height keep increasing during the whole rainfall process under the single-peak and uniform type of rainfall in July and September. The shortest response time of the pore water pressure of the point with the height of $81.975 \mathrm{~m}$ appears in Figure 9(b) among the three rainfall patterns, which is attributed to the largest rainfall in early August. In contrast, 


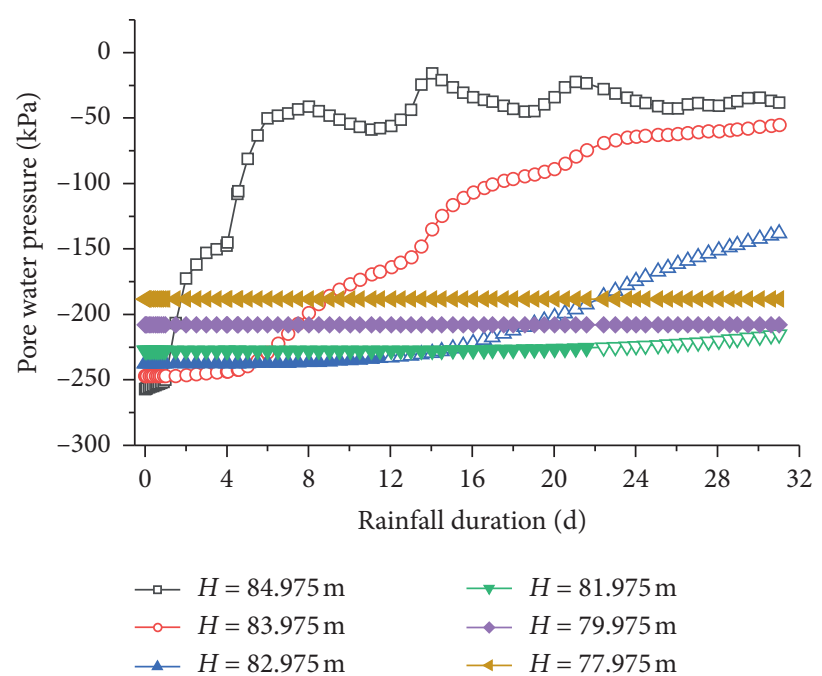

(a)

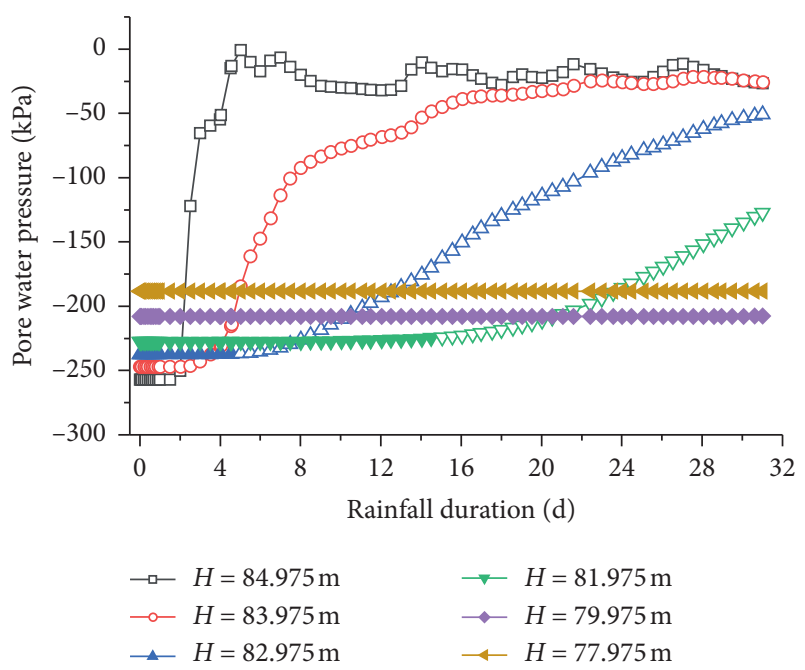

(b)

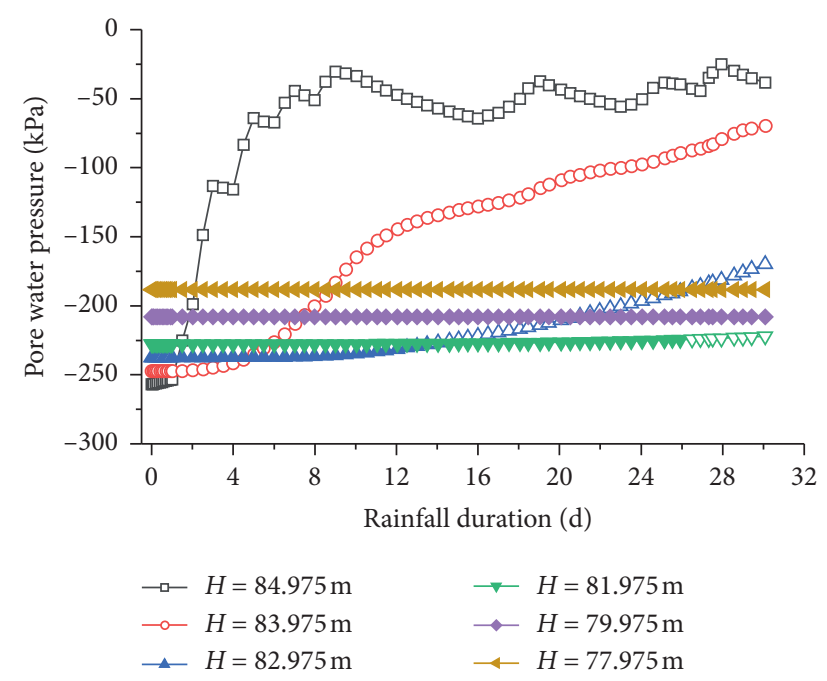

(c)

Figure 9: Pore water pressure distribution of monitor points in the slope under the rainfall pattern of (a) single-peak; (b) wave; (c) uniform.

the response time of the point with the same height in July and September is the 23rd and 26th days, respectively. At the end of the rainfall pattern, the increase of the pore water pressure in September is slight, which means that the wetting front just moves to this height.

Figure 10 shows the plastic zone distributions and pore water pressure contour of the slope after rainfall under different rainfall patterns. Compared with the plastic zone distribution of the slope before rainfall in Figure 8(b), shallow regions of silty clay have been in the yield status in Figure 10. Besides, the linear plastic zones are observed under the excavation stages and the largest plastic zone appears in Figure 10(b). The reason for the added plastic zone is given as the decrease of the shear strength due to the increase of pore water pressure. Therefore, the position of the plastic zones inside the slope has a close relationship with the pore water pressure variation area according to the pore water pressure contour. The plastic zones in the strongly weathered silty mudstone region in Figures 10(b) and 10(c) have already connected to the ones in the silty clay region, and several small transient saturated zones could also be observed inside the plastic zone. The comparison of pore water pressure contours of the slope under different rainfall patterns reveals that the more rainfall leads to a larger pore water pressure increase and higher fluctuation in the groundwater level. The rainfall amount in July and September is close, but the increase of groundwater level in Figure 10(c) is much larger than that in Figure 10(a), which could be explained by the strong rainfall that occurred at the end of September.

In order to reveal the influence of rainfall patterns on the slope stability, Figure 11 presents the variations of the factor 

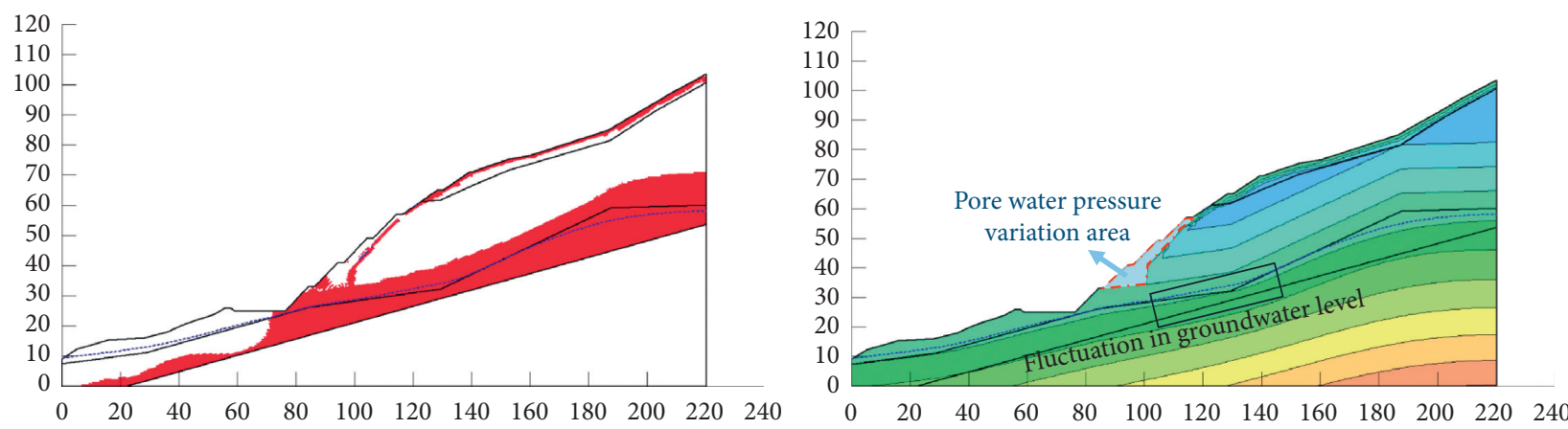

Pore-water pressure

口 -300 to $-220 \mathrm{kPa}$

ㅁ 180 to $260 \mathrm{kPa}$

-220 to $-140 \mathrm{kPa}$

260 to $340 \mathrm{kPa}$

ㅁ -140 to $-60 \mathrm{kPa}$

口 340 to $420 \mathrm{kPa}$

口 -60 to $20 \mathrm{kPa}$

口 420 to $500 \mathrm{kPa}$

20 to $100 \mathrm{kPa}$

500 to $580 \mathrm{kPa}$

ㅁ 100 to $180 \mathrm{kPa}$

(a)
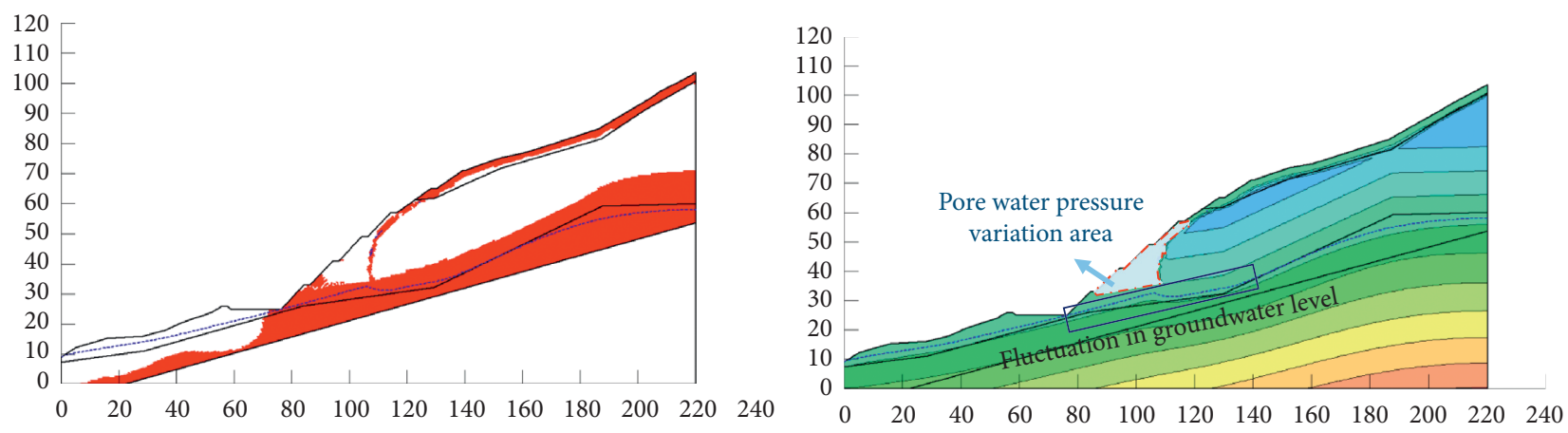

Pore-water pressure

口 $\leq-300$ to $-220 \mathrm{kPa}$

180 to $260 \mathrm{kPa}$

ㅁ -220 to $-140 \mathrm{kPa}$

口 260 to $340 \mathrm{kPa}$

ㅁ -140 to $-60 \mathrm{kPa}$

口 340 to $420 \mathrm{kPa}$

ㅁ -60 to $20 \mathrm{kPa}$

口 420 to $500 \mathrm{kPa}$

20 to $100 \mathrm{kPa}$

口 $\geq 500 \mathrm{kPa}$

- 100 to $180 \mathrm{kPa}$

(b)

Figure 10: Continued. 

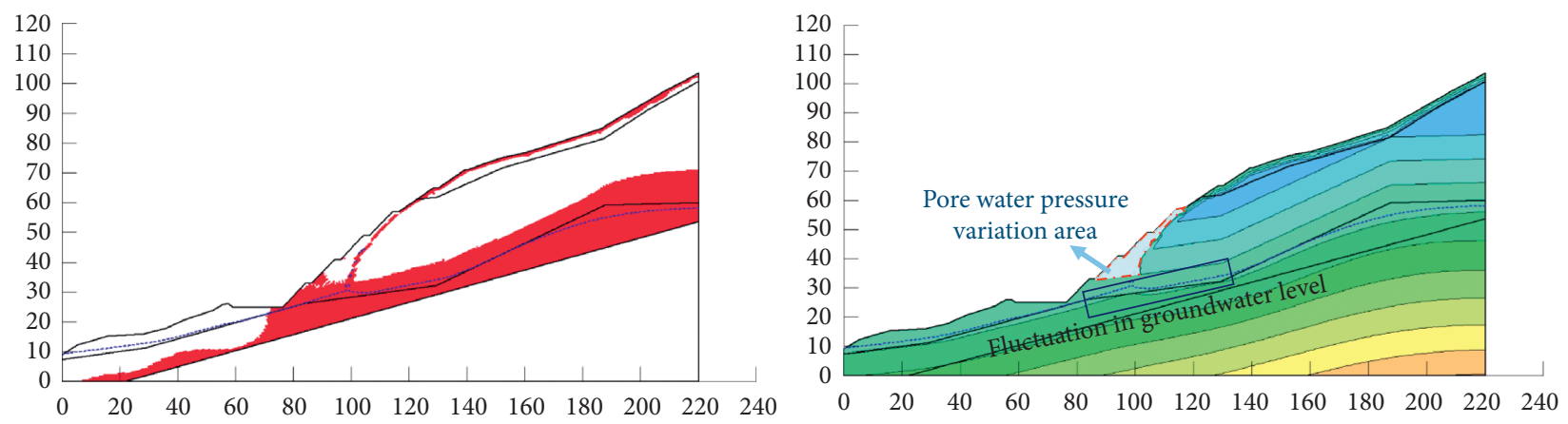

$\begin{array}{ll}\text { Pore-water pressure } & \\ \square-300 \text { to }-220 \mathrm{kPa} & \square 180 \text { to } 260 \mathrm{kPa} \\ \square-220 \text { to }-140 \mathrm{kPa} & \square 260 \text { to } 340 \mathrm{kPa} \\ \square-140 \text { to }-60 \mathrm{kPa} & \square 340 \text { to } 420 \mathrm{kPa} \\ \square-60 \text { to } 20 \mathrm{kPa} & \square 420 \text { to } 500 \mathrm{kPa} \\ \square 20 \text { to } 100 \mathrm{kPa} & \square 500 \text { to } 580 \mathrm{kPa} \\ \square-100 \text { to } 180 \mathrm{kPa} & \square 580 \text { to } 660 \mathrm{kPa}\end{array}$

(c)

FIGURE 10: Plastic zone distribution and pore water pressure contour of the slope after rainfall with the type of (a) single-peak; (b) wave; (c) uniform.

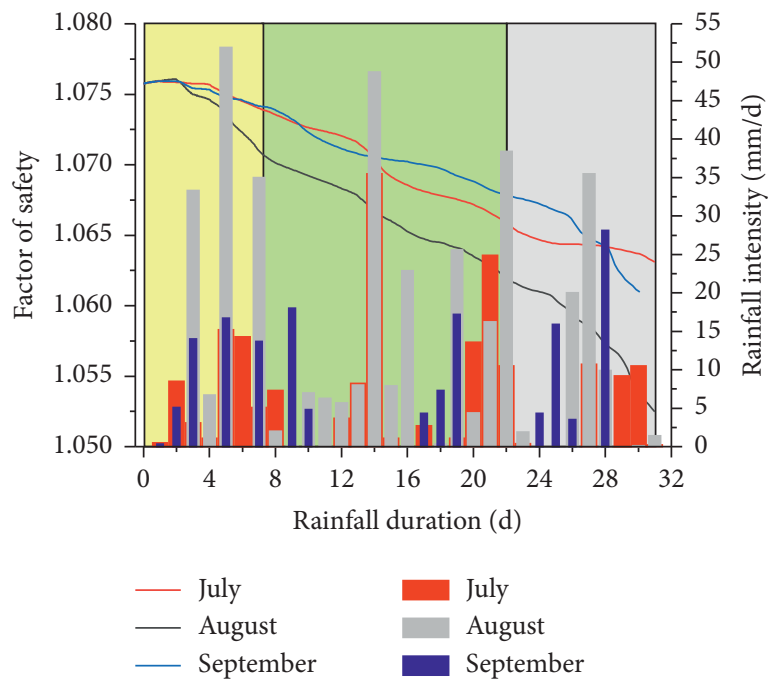

FIGURE 11: Factor of safety of the potential sliding surface of the slope subjected to different rainfall patterns.

of safety of the potential sliding surface of the slope during the rainfall process subjected to different rainfall patterns. The results show that the largest decrease in the factor of safety of the potential sliding surface is observed as 0.023 after 31-day wave-type of rainfall utilizing the data in $\mathrm{Au}$ gust, while the decrease of the factor of safety after the other two rainfall patterns is 0.012 and 0.0145 , respectively. Besides, the decreasing trend of the factor of safety is related to the rainfall intensity. The higher the rainfall intensity is, the faster decrease velocity of the value is. In the first 7 days (marked as the yellow region in Figure 11), the rainfall intensity of the wave-type is the largest, while the ones in the uniform and single-peak type are all smaller than $15 \mathrm{~mm} / \mathrm{d}$. Therefore, the only curve for the slope subjected to wave- type rainfall shows an obvious decrease, while the variations in the factor of safety of the other two curves are similar. During the middle stage of the rainfall process (marked as the green region), especially for $t=14 \mathrm{~d}$, the high rainfall intensities are observed in July and August. A fast decrease could be found in the curve of the slope subjected to singlepeak and uniform type of rainfall in the period of $t=13 \mathrm{~d} \sim 16 \mathrm{~d}$. In the final part of the rainfall, there is a rainfall event on September 24 to 28 with two days' rainfall intensity being much larger than $15 \mathrm{~mm} / \mathrm{d}$. Therefore, the factor of safety at the end of rainfall in September shows a sudden decrease. The pore water pressure contours in Figure 10 show that the influence of rainfall on the slope stability is concentrated on the pore water pressure variation area near 
the excavation face and the fluctuation of the groundwater level. The comparisons of the seepage field in the slope under different rainfall patterns reveal that the rainfall amount and intensity distribution have an impact on the distribution of pore water pressure and plastic zone. According to the unsaturated strength theory, the increase in pore water pressure would lead to a decrease in effective stress and shear strength. Therefore, the stability of the slope subjected to the wave-type rainfall (August) is the most sensitive to the rainfall. Although the rainfall in July is a little larger than that in September, the uniform type of rainfall shows a greater threat to the slope stability.

\subsection{Effect of Anisotropic Permeability of Crack on the Slope} Stability. According to the field observation, there was an obvious crack in the shallow silty clay region due to excavation, which was located at a horizontal distance of about $92 \mathrm{~m}$ from the final stage of the excavation. Considering the influence of fillings inside the crack on the permeability anisotropy, three types of anisotropic permeability were set as the permeability ratios of $0.1,1.0$, and 10 . To present the pore water pressure variations in the slope with different degrees of anisotropic permeability subjected to the wavetype rainfall, several monitor points are set in segment 2 located below the crack at the height of $61.825 \mathrm{~m}$ as shown in Figure 6. The results in Figure 12 show that the values of pore water pressure of the points of which the horizontal ordinate is in the range of $168-172 \mathrm{~m}$ at the same height have increased to $0 \mathrm{kPa}$ after 5-10 days' rainfall, while the values of the points outside the range increase continually during the whole rainfall. The anisotropic degree in the permeability of the crack has an obvious influence on the variation range and speed of the pore water pressure. According to the variation range, the range of horizontal ordinate of the monitor points with pore water pressure variation during the rainfall is divided into two parts as region $\mathrm{A}$ and region B. Region A covers the horizontal range of the monitor points whose pore water pressure has already reached the stable value close to $0 \mathrm{kPa}$ after $15 \mathrm{~d}$ rainfall. Region $\mathrm{B}$ covers the horizontal range of the monitor points whose pore water pressure shows continuous increase during the whole rainfall process. The comparison among three pore water pressure distributions in Figure 12 shows that the smallest width of region A appears in the cracking slope with the permeability ratio of 0.1 (Figure $12(\mathrm{a})$ ), which means that the variation range of pore water pressure in the slope with $\eta=0.1$ is the smallest under the same rainfall pattern. The largest width of pore water pressure variation region (the sum of regions $\mathrm{A}$ and $\mathrm{B}$ ) is observed in the cracking slope with a permeability coefficient ratio of 10.0 beginning from $x=165 \mathrm{~m}$ to $176 \mathrm{~m}$. After $3.5-3.6 \mathrm{~d}$ rainfall, one monitor point located in region $\mathrm{A}$ in the cracking slope with permeability ratio of 1.0 and 10 has increased from $-105.52 \mathrm{kPa}$ to $2.44 \mathrm{kPa}$, which means that the rainfall infiltration from the crack has already moved to this depth. The similar situation in the slope with permeability ratio of 0.1 costs more time: the pore water pressure of the points located in region $\mathrm{A}$ increased above $0 \mathrm{kPa}$ after $5.4 \mathrm{~d}$ rainfall. Only in the slope with isotropic crack (permeability ratio of 1.0) are the widths of the two parts of region B equal and symmetrically located on both sides of region A.

The pore water pressure contour of the cracking slope after rainfall in Figure 13 shows that the pore water pressure variation area is located primarily below the crack region and the excavation region. The cracking slope with a permeability ratio of 10.0 covers the maximum pore water pressure area and the highest rise of the groundwater level. Figure 13 reveals that a lower permeability ratio leads to the bias of the infiltration towards the normal direction and a lower infiltration velocity in the tangential direction, which also results in a lower total saturated permeability coefficient based on the given saturated permeability in the normal direction. Therefore, the rainfall infiltration from the anisotropic crack with a permeability ratio of 0.1 shows a tendency towards the horizontal direction rather than the tangential direction of the crack in the other two slopes. As a result, the response of the pore water pressure of the monitor points in the left part of region B is the lowest and smallest in the cracking slope with the permeability ratio of 0.1 among three cracking cases.

The distributions of the plastic zone are similar in the cracking slope with the permeability ratios of $0.1,1.0$, and 10 . The plastic zone and potential sliding surface of the cracking slope with the permeability ratio of 1.0 after rainfall are presented in Figure 14 as an example. Compared with the plastic zone in the completed slope after the same rainfall, as shown in Figure 10(b), there is an obvious ascending region near the groundwater level below the crack region, which is close to the left boundary of the pore water pressure variation area in the contour.

The locations of the potential sliding surfaces in three types of cracking slope are also shown in Figure 15. Due to the similarities in the plastic zone distribution in the cracking slope with different anisotropic permeabilities, the position and shape of the potential sliding surfaces in three cases are also alike, and the higher height in the groundwater level in the slices is observed in Figures 15(b) and 15(c). To present the influence of crack on the potential sliding surface, the pore water pressure of the mid-point of the slice base of three types of the slope was collected during the rainfall. According to the various characteristics of the pore water pressure along the potential sliding surface in Figure 15, the potential sliding body is divided into three regions: the rainfall infiltration influence region, the groundwater level influence region, and the combined effect region. The rainfall infiltration influence region could be further divided into the crack infiltration and surface 


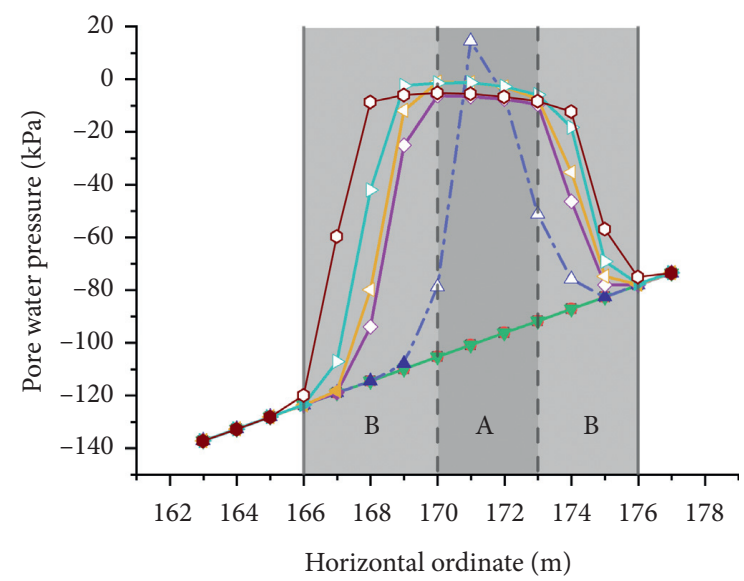

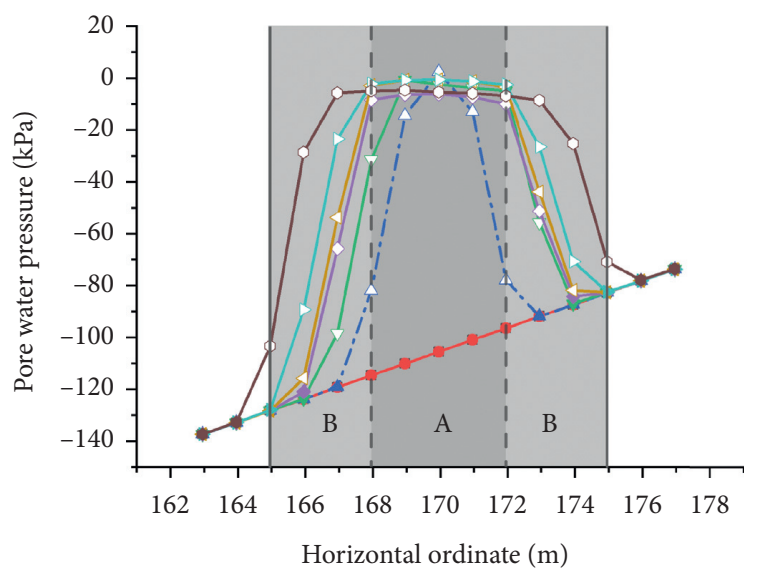

$\rightarrow t=0 \mathrm{~d}$
$\longrightarrow t=3 \mathrm{~d}$
$-t=3.5 \mathrm{~d}$
$\hookrightarrow t=5 \mathrm{~d}$

$\rightarrow-t=10 \mathrm{~d}$

$\longleftarrow t=15 \mathrm{~d}$

$\rightarrow t=20 \mathrm{~d}$

$\longrightarrow t=31 \mathrm{~d}$

(a)

(b)

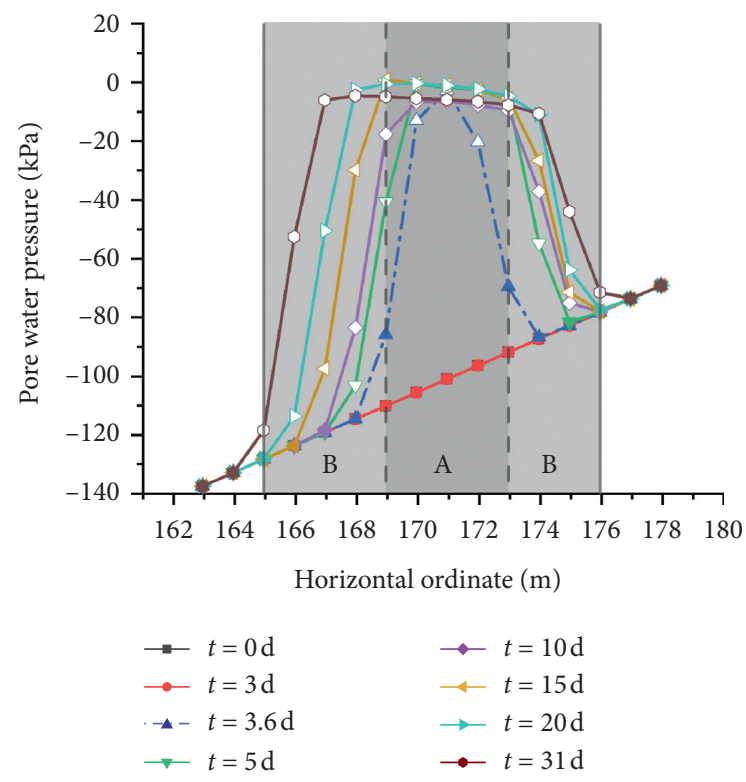

(c)

Figure 12: Pore water pressure distribution of the cracking slope with an anisotropic degree of permeability as (a) 0.1 ; (b) 1.0 ; (c) 10 .

infiltration. The pore water pressure of the points located in the rainfall infiltration influence region first shows an increase after $3 \mathrm{~d}$ rainfall, which is only caused by the rainfall infiltration. The pore water pressure in the groundwater level influence region starts to increase in the middle-final part of the rainfall, and the range of the horizontal ordinates of the points in this region is within $x=110-170 \mathrm{~m}$. Compared with the potential sliding surface position, this region is located in the groundwater level fluctuation region. The rainfall moves from the crack to the toe of the slope continually under gravity and matric suction, which costs a little time. Therefore, the response of the pore water pressure in this region is a little slower than the one in the rainfall infiltration region. The combined effect region is located near the toe of the slope, where the rainfall infiltration and groundwater level fluctuation both influence the pore water 

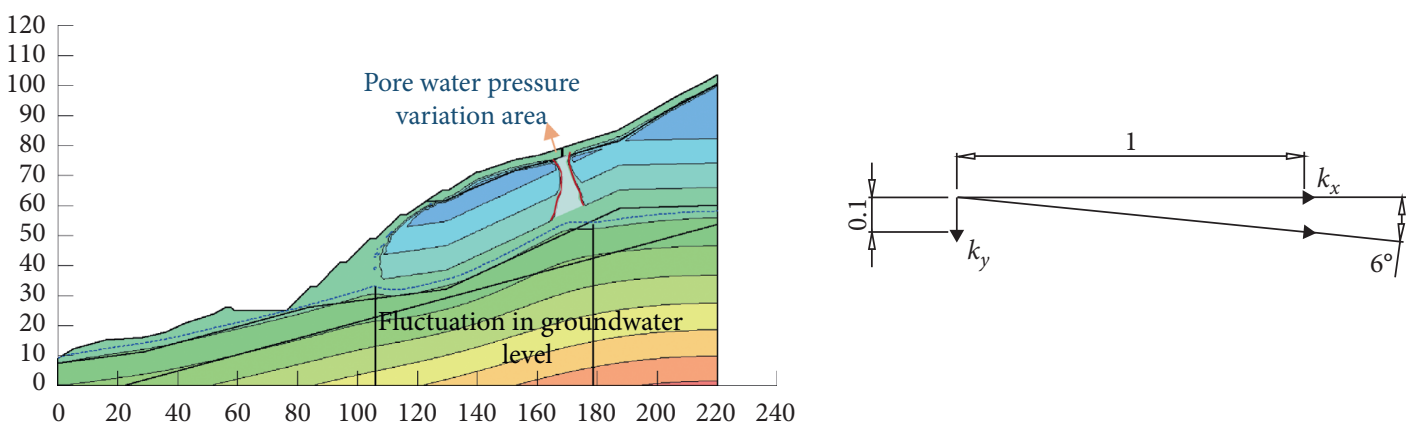

Pore-water pressure

\section{口 -300 to $-220 \mathrm{kPa}$}

ㅁ 180 to $260 \mathrm{kPa}$

ㅁ -220 to $-140 \mathrm{kPa}$

260 to $340 \mathrm{kPa}$

ㅁ -140 to $-60 \mathrm{kPa}$

口 340 to $420 \mathrm{kPa}$

口 -60 to $20 \mathrm{kPa}$

420 to $500 \mathrm{kPa}$

口 20 to $100 \mathrm{kPa}$

口 500 to $580 \mathrm{kPa}$

100 to $180 \mathrm{kPa}$

(a)
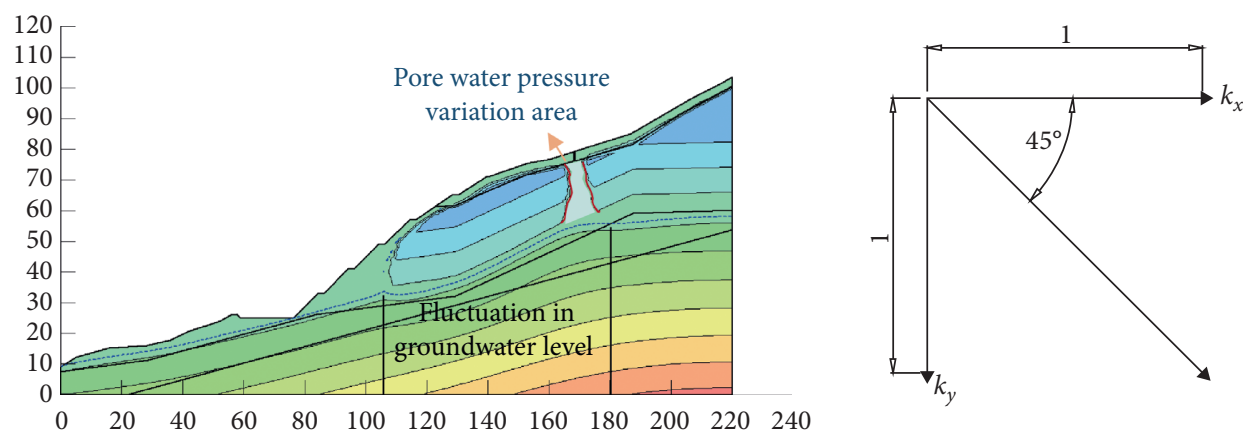

Pore-water pressure

口 -300 to $-220 \mathrm{kPa}$

180 to $260 \mathrm{kPa}$

口 -220 to $-140 \mathrm{kPa}$

口 260 to $340 \mathrm{kPa}$

ㅁ -140 to $-60 \mathrm{kPa}$

ㅁ 340 to $420 \mathrm{kPa}$

ㅁ -60 to $20 \mathrm{kPa}$

口 420 to $500 \mathrm{kPa}$

口 20 to $100 \mathrm{kPa}$

口 500 to $580 \mathrm{kPa}$

口 100 to $180 \mathrm{kPa}$

(b)

Figure 13: Continued. 


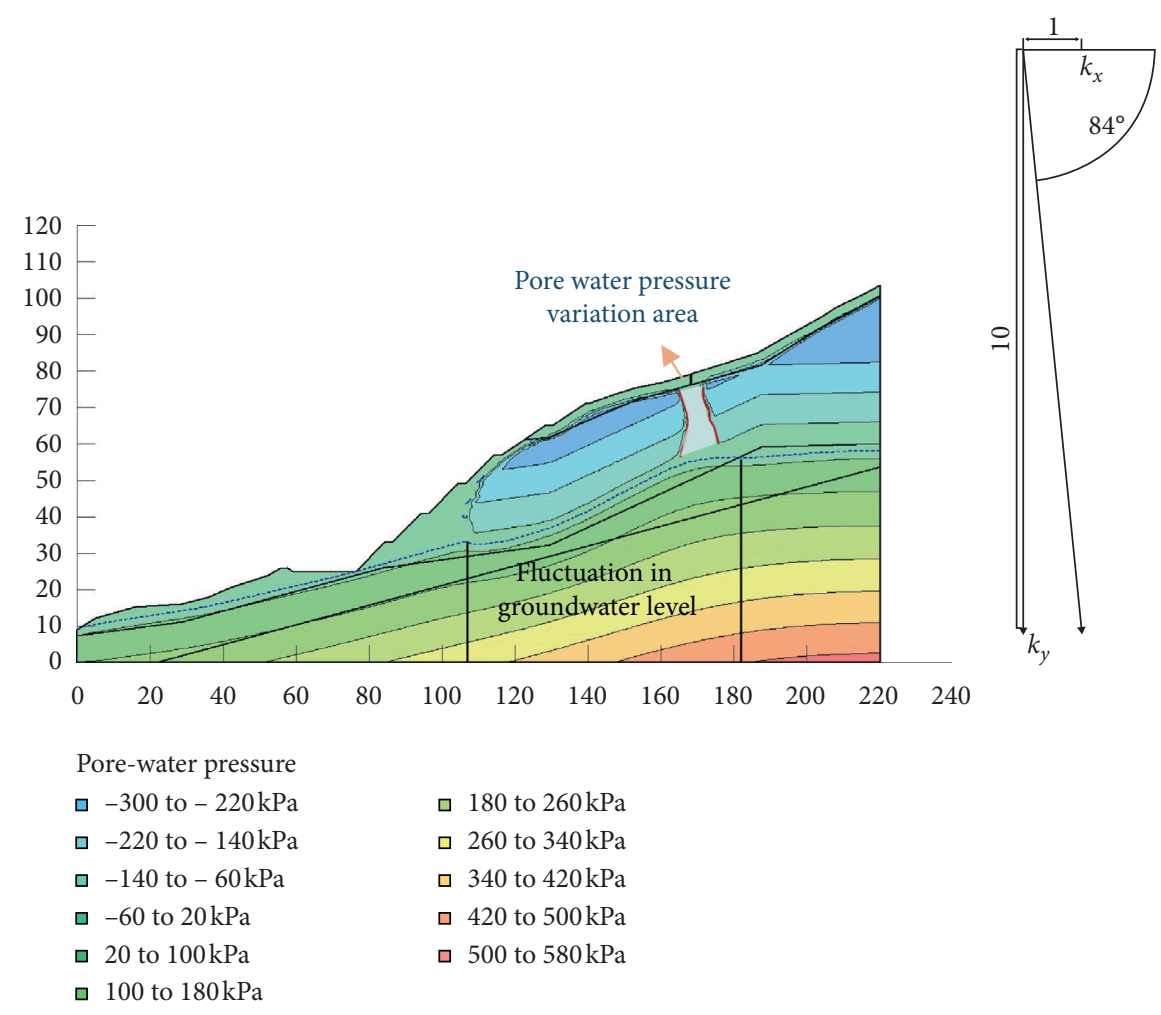

(c)

Figure 13: Pore water pressure contour of the cracking slope with permeability ratio as (a) 0.1 ; (b)1.0; (c) 10 after rainfall.

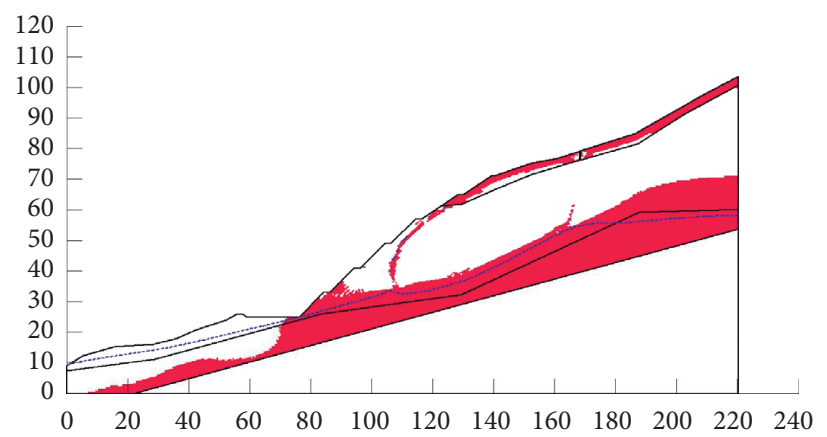

FIgURE 14: Plastic zone distribution of the cracking slope with permeability ratio as 1.0 after rainfall.

pressure. The differences in the pore water pressure in the cracking slope with different permeability ratios are not significant, which could be explained by the same rainfall condition in three calculation cases.

Figure 16 presents the values of the factor of safety of the potential sliding surface of the completed slope and cracking slope with various permeability ratios. The results show that, under the same rainfall condition, the difference in the decrease in the factor of safety between the completed and cracking slopes is notable, which demonstrates the direct effect of the crack on the slope stability. The decreases in the factor of safety of the cracking slope increase from 0.055 to 0.076 during the rainfall as the permeability ratio increases. The discussions about the seepage field features above reveal that a higher permeability ratio means a greater tangential permeability coefficient, which plays an important role in 

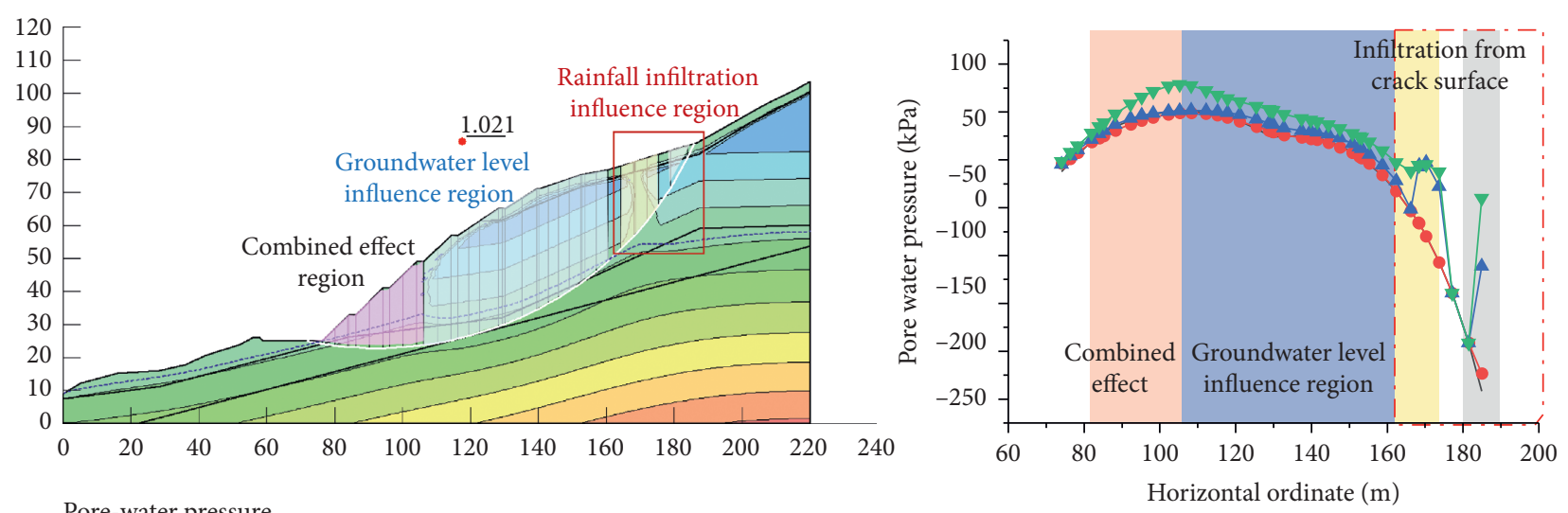

Pore-water pressure

口 -300 to $-220 \mathrm{kPa}$

口 -220 to $-140 \mathrm{kPa}$

180 to $260 \mathrm{kPa}$

$\begin{array}{ll}\longrightarrow t=0 \mathrm{~d} & \longrightarrow t=18 \mathrm{~d} \\ -t=3 \mathrm{~d} & \longrightarrow t=31 \mathrm{~d}\end{array}$

ㅁ -140 to $-60 \mathrm{kPa}$

口 260 to $340 \mathrm{kPa}$

ㅁ 340 to $420 \mathrm{kPa}$

口 420 to $500 \mathrm{kPa}$

口 -60 to $20 \mathrm{kPa}$

500 to $580 \mathrm{kPa}$

20 to $100 \mathrm{kPa}$

口 100 to $180 \mathrm{kPa}$

(a)
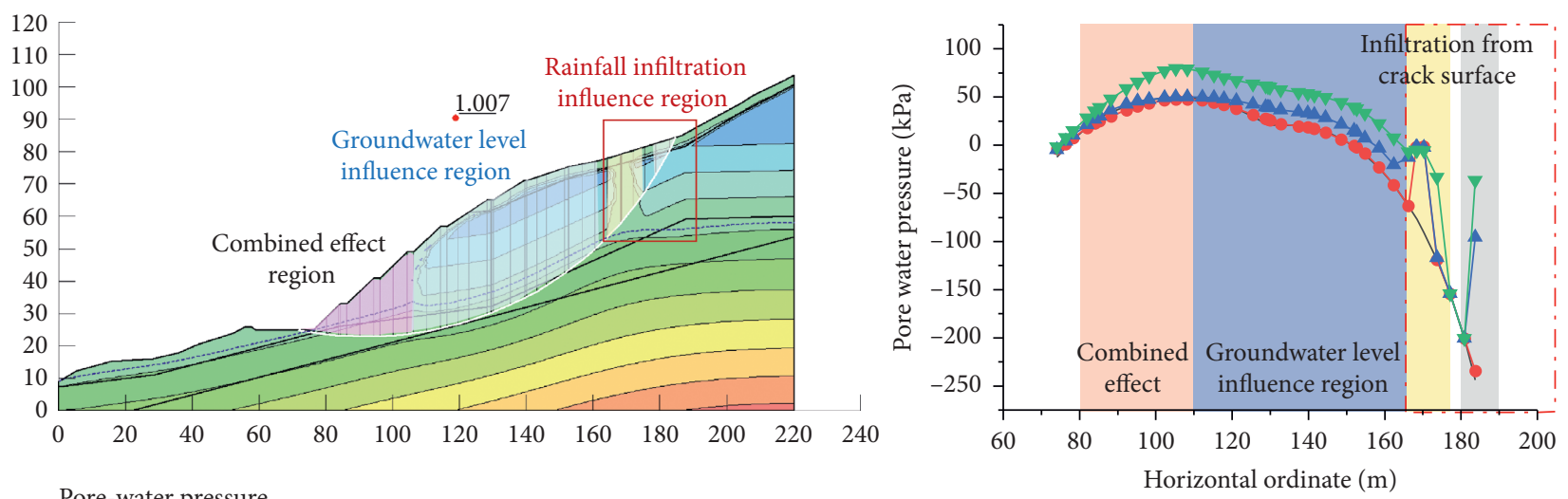

Pore-water pressure

口 -300 to $-220 \mathrm{kPa}$

ㅁ 180 to $260 \mathrm{kPa}$

ㅁ -220 to $-140 \mathrm{kPa}$

口 260 to $340 \mathrm{kPa}$

ㅁ -140 to $-60 \mathrm{kPa}$

口 340 to $420 \mathrm{kPa}$

ㅁ -60 to $20 \mathrm{kPa}$

口 420 to $500 \mathrm{kPa}$

ㅁ 20 to $100 \mathrm{kPa}$

口 500 to $580 \mathrm{kPa}$

$t=0 \mathrm{~d}$

$\simeq t=18 \mathrm{~d}$

$\longrightarrow t=3 \mathrm{~d}$

$\checkmark t=31 \mathrm{~d}$

(b)

FIgUre 15: Continued. 

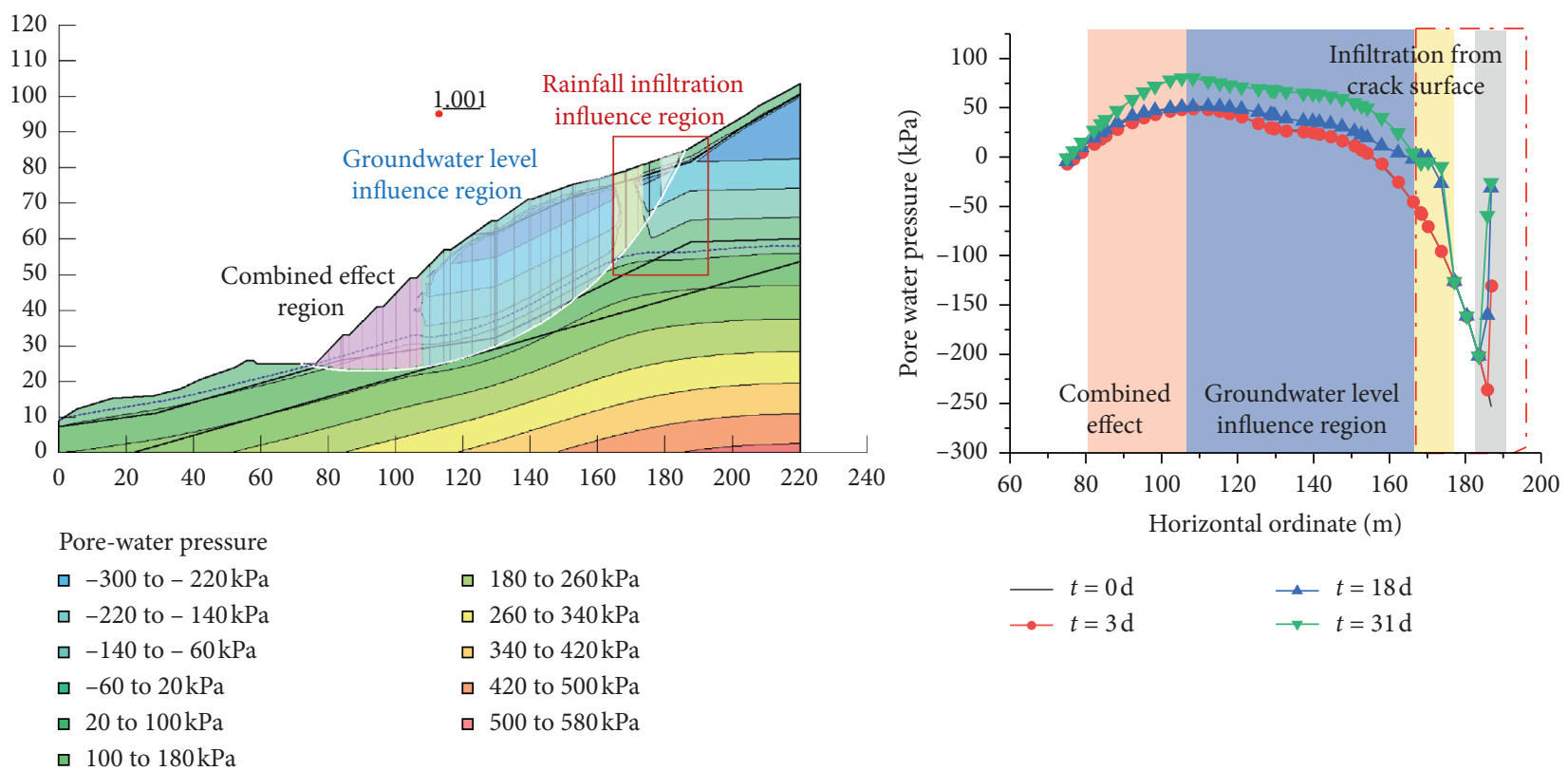

(c)

FIGURE 15: The potential sliding surface and pore water pressure distribution of the cracking slope with the permeability ratio of (a) 0.1 ; (b) 1.0 ; (c) 10 .

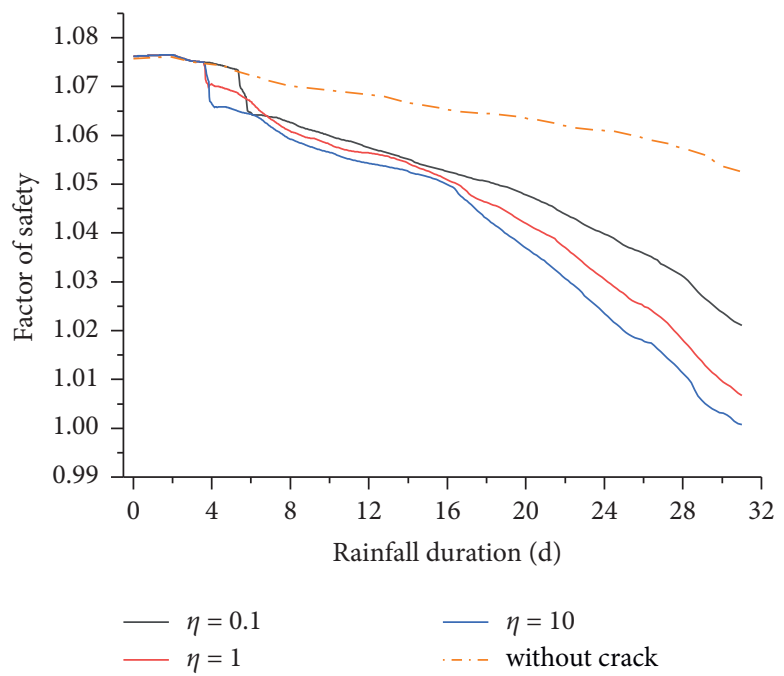

FIGURE 16: Factor of safety of the potential sliding surface of the slope during the rainfall.

accelerating rainfall movement to the groundwater level and pore water pressure increase. The variations in the seepage field have a negative effect on the effective stress and shear strength, which leads to a reduction in the slope stability directly.

\section{Conclusions}

It is significant to understand the stability and failure mechanism of the red bed slope subjected to rainfall to utilize effective measures to avoid their occurrence. In this study, a typical red bed slope in Yunnan, China, is selected to analyze the red bed slope stability and seepage field distribution during the rainfall process. The effects of actual rainfall patterns and the crack on the seepage and stability of the slope are discussed in the paper. The results show that the pore water pressure variation region is concentrated in the shallow region of the completed slope during the rainfall. The plastic zone distribution is closely related to the pore water pressure variation area, and the greater rainfall is, the larger the plastic zone is. The decrease rate of the factor of safety of the potential sliding surface of the completed slope coincides with the rainfall intensity, and the largest rainfall amount in August induced the smallest factor of safety. 
Although the rainfall amounts in July and September are similar, the slope under the uniform type of rainfall is more prone to damage due to the strong rainfall intensity at the end of the process. The impact of the crack on the seepage field and slope stability is obvious and noticeable, which provides the preferential channels for rainwater. The anisotropic permeability coefficients of crack have various impacts on the distribution of pore water pressure inside the slope: the increase of tangential permeability accelerates tangential infiltration rate and leads to a greater increasing area of pore water pressure. Therefore, the slope with a higher tangential permeability crack is more vulnerable under the same rainfall duration.

\section{Data Availability}

The table and figure data used to support the findings of this study are available from the corresponding author upon request.

\section{Conflicts of Interest}

The authors declare that there are no conflicts of interest regarding the publication of this paper.

\section{Acknowledgments}

The authors are grateful for the financial supports provided by the National Key R\&D Program of China (no. 2018YFC0809400), the International Partnership Program of Chinese Academy of Sciences (Grant no. 131551KYSB20180042), the National Natural Science Foundation of China (Grant nos. 51779250, 51679232, 51609240, and 51909259), and the Science and Technology R\&D Project of China State Construction International Holdings Limited (Grant no. CSCI-2020-Z-21).

\section{References}

[1] P. Hoffman, "Proterozoic paleocurrents and depositional history of the east arm fold belt, great slave lake, northwest territories," Canadian Journal of Earth Sciences, vol. 6, pp. 441-462, 2011.

[2] F. B. V. Houten, "Origin of red beds a review-1961-1972," Annual Review of Earth and Planetary Sciences, vol. 1, no. 1, pp. 39-61, 1973.

[3] M. Wagreich and H.-G. Krenmayr, "Upper cretaceous oceanic red beds (CORB) in the Northern calcareous alps (nierental formation, Austria): slope topography and clastic input as primary controlling factors," Cretaceous Research, vol. 26, no. 1, pp. 57-64, 2005.

[4] G. Li, G. Jiang, and X. Wan, "The age of the chuangde formation in kangmar, southern Tibet of China: implications for the origin of cretaceous oceanic red beds (CORBs) in the northern tethyan Himalaya," Sedimentary Geology, vol. 235, no. 1-2, pp. 111-121, 2011.

[5] Y. L. Liu, X. L. Tian, R. Liu, S. L. Liu, and A. V. Zuza, "Key driving factors of selenium-enriched soil in the low-se geological belt: a case study in red beds of sichuan basin, China," Catena, vol. 196, Article ID 104926, 2020.

[6] K. Uno and K. Furukawa, "Timing of remanent magnetization acquisition in red beds: a case study from a syn-folding sedimentary basin," Tectonophysics, vol. 406, no. 1-2, pp. 67-80, 2005.

[7] L.-b. Yan and M. Kasanin-Grubin, "Land degradation and management of red beds in China: two case studies," Journal of Mountain Science, vol. 16, no. 11, pp. 2591-2604, 2019.

[8] W. G. Zuo, "Study on engineering property of cretaceous system and teriary red beds in hunan province," M. Sc. thesis, Central South University, Hunan, China, 2006.

[9] H. Miao, G. Wang, K. Yin, T. Kamai, and Y. Li, "Mechanism of the slow-moving landslides in jurassic red-strata in the three gorges reservoir, China," Engineering Geology, vol. 171, pp. 59-69, 2014.

[10] J. Geng and L. Cao, "Failure analysis of water-bearing sandstone using acoustic emission and energy dissipation," Engineering Fracture Mechanics, vol. 231, Article ID 107021, 2020.

[11] M. U. Azhar, H. Zhou, F. Yang et al., "Water-induced softening behavior of clay-rich sandstone in lanzhou water supply project, China," Journal of Rock Mechanics and Geotechnical Engineering, vol. 12, no. 3, pp. 557-570, 2020.

[12] Z. Zhang, L. Han, S. Wei, L. Chen, and G. Liu, "Disintegration law of strongly weathered purple mudstone on the surface of the drawdown area under conditions of three gorges reservoir operation," Engineering Geology, vol. 270, Article ID 105584, 2020.

[13] E. N. Zhang and M. L. Ibsen, "Bedding-controlled coastal landslides in southeast britain between axmouth and the thames estuary," Landslides, vol. 1, no. 2, pp. 131-141, 2004.

[14] D. Park and R. L. Michalowski, "Three-dimensional stability analysis of slopes in hard soil/soft rock with tensile strength cut-off," Engineering Geology, vol. 229, pp. 73-84, 2017.

[15] Z. Chitu, T. Bogaard, A. Busuioc, S. Burcea, I. Sandric, and M.-J. Adler, "Identifying hydrological pre-conditions and rainfall triggers of slope failures at catchment scale for 2014 storm events in the Ialomita Subcarpathians, Romania," Landslides, vol. 14, no. 1, pp. 419-434, 2017.

[16] X.-Z. Chen and Y.-F. Cui, "The formation of the Wulipo landslide and the resulting debris flow in Dujiangyan City, China," Journal of Mountain Science, vol. 14, no. 6, pp. 1100-1112, 2017.

[17] H. Lin and W. Zhong, "Influence of rainfall intensity and its pattern on the stability of unsaturated soil slope," Geotechnical and Geological Engineering, vol. 37, no. 2, pp. 615-623, 2019.

[18] T. Chaithong, "Determination critical rainfall threshold for the initiation of landslides using rainfall-infiltration model and infinite slope stability model," in Geoinformatics for Sustainable Development in Asian Cities. ICGGS 2018, S. Monprapussorn, Z. Lin, A. Sitthi, and P. Wetchayont, Eds., Springer Geography. Springer, Berlin, Germany, 2020.

[19] A. N. C. Ghani, A. M. Taib, and D. Z. A. Hasbollah, "Effect of rainfall pattern on slope stability," in Geotechnics for Sustainable Infrastructure Development, P. Duc Long and N. Dung, Eds., Springer, Berlin, Germany, 2020.

[20] M. S. Kim, Y. Onda, T. Uchida, J. K. Kim, and Y. S. Song, "Effect of seepage on shallow landslides in consideration of changes in topography: case study including an experimental sandy slope with artificial rainfall," Catena, vol. 161, pp. 5062, 2018.

[21] T. Y. Wu, J. H. Jia, N. Jiang, C. B. Zhou, X. D. Luo, and Y. Q. Xia, "Model test of deformation evolution and multi factor prediction of anchorage slope stability under rainfall condition," Journal of Earth Science, vol. 32, 2020.

[22] Y. C. Yang, H. G. Xing, X. G. Yang, M. L. Chen, and J. W. Zhou, "Experimental study on the dynamic response and 
stability of bedding rock slopes with weak interlayers under heavy rainfall," Environmental Earth Sciences, vol. 77, no. 12, 2018.

[23] L. Z. Wu, L. M. Zhang, Y. Zhou et al., "Theoretical analysis and model test for rainfall-induced shallow landslides in the red-bed area of Sichuan," Bulletin of Engineering Geology and the Environment, vol. 77, no. 4, pp. 1343-1353, 2018.

[24] Y. Xu, J. Li, H. Fan, L. Chen, Y. Zhao, and L. Li, "Stability analysis of clastic rock slope with mudstone interlayer under rainfall infiltration," Geotechnical and Geological Engineering, vol. 35, no. 4, pp. 1871-1883, 2017.

[25] K. Mahmood, J. M. Kim, H. Khan, M. Safdar, and U. Khan, "The probabilistic stability analysis of saturated-unsaturated $\mathrm{MH}$ and CL Soil Slope with rainfall infiltration," KSCE Journal of Civil Engineering, vol. 22, no. 5, pp. 1742-1749, 2018.

[26] S. Y. Fan, Z. P. Song, Y. W. Zhang, and N. F. Liu, "Case study of the effect of rainfall infiltration on a tunnel underlying the roadbed slope with weak inter-layer," KSCE Journal of Civil Engineering, vol. 24, 2020.

[27] P.-T. Yeh, K. Z.-Z. Lee, and K.-T. Chang, "3D effects of permeability and strength anisotropy on the stability of weakly cemented rock slopes subjected to rainfall infiltration," Engineering Geology, vol. 266, Article ID 105459, 2020.

[28] S. M. Ng, M. A. M. Ismail, and I. Abustan, "Development of groundwater level fluctuation response system subjected to rainfall for slope stability forecasting," Journal of the Geological Society of India, vol. 96, no. 6, pp. 616-622, 2020.

[29] A. Kaya and Ü yae Midilli, "Slope stability evaluation and monitoring of a landslide: a case study from Ne Turkey," Journal of Mountain Science, vol. 17, no. 11, pp. 2624-2635, 2020.

[30] B.-Q.-V. Nguyen, S.-R. Lee, and Y.-T. Kim, "Spatial probability assessment of landslide considering increases in porewater pressure during rainfall and earthquakes: case studies at Atsuma and Mt. Umyeon," Catena, vol. 187, Article ID 104317, 2020.

[31] L. Ayalew and H. Yamagishi, "The application of Gis-based logistic regression for landslide susceptibility mapping in the kakuda-yahiko mountains, Central Japan," Geomorphology, vol. 65 , no. 1-2, pp. 15-31, 2005.

[32] S. Y. Liu, Z. N. Su, M. Li, and L. T. Shao, "Slope stability analysis using elastic finite element stress fields," Engineering Geology, vol. 273, Article ID 105673, 2020.

[33] D. G. Milledge, D. Bellugi, J. A. McKean, A. L. Densmore, and W. E. Dietrich, "A multidimensional stability model for predicting shallow landslide size and shape across landscapes," Journal of Geophysical Research: Earth Surface, vol. 119, no. 11, pp. 2481-2504, 2014.

[34] M. Mergili, I. Marchesini, M. Rossi, F. Guzzetti, and W. Fellin, "Spatially distributed three-dimensional slope stability modelling in a raster GIS," Geomorphology, vol. 206, pp. 178-195, 2014.

[35] Y. Zheng, C. Chen, F. Meng, T. Liu, and K. Xia, "Assessing the stability of rock slopes with respect to flexural toppling failure using a limit equilibrium model and genetic algorithm," Computers and Geotechnics, vol. 124, Article ID 103619, 2020.

[36] N. Jia, Z. Yang, M. Xie, Y. Mitani, and J. Tong, "Gis-based three-dimensional slope stability analysis considering rainfall infiltration," Bulletin of Engineering Geology and the Environment, vol. 74, no. 3, pp. 919-931, 2015.

[37] E. Bahsan, H.-J. Liao, J. Ching, and S.-W. Lee, "Statistics for the calculated safety factors of undrained failure slopes," Engineering Geology, vol. 172, pp. 85-94, 2014.
[38] B. Leshchinsky, F. Vahedifard, H.-B. Koo, and S.-H. Kim, "Yumokjeong Landslide: an investigation of progressive failure of a hillslope using the finite element method," Landslides, vol. 12, no. 5, pp. 997-1005, 2015.

[39] H. Xue, F. Dang, X. Yin, and W. Ding, "Unified overload method of slope stability analysis based on potential sliding direction," KSCE Journal of Civil Engineering, vol. 22, no. 9, pp. 3254-3262, 2018.

[40] S. Lu and G. H. Sun, "Improvement of the finite-elementbased limit equilibrium method to include changes in groundwater: a case study of a deforming bank slope from the three gorges reservoir," Environmental Earth Sciences, vol. 77, no. 9, 2018.

[41] S. Oh and N. Lu, "Slope stability analysis under unsaturated conditions: case studies of rainfall-induced failure of cut slopes," Engineering Geology, vol. 184, pp. 96-103, 2015.

[42] S.-H. Jiang, J. Huang, X.-H. Qi, and C.-B. Zhou, "Efficient probabilistic back analysis of spatially varying soil parameters for slope reliability assessment," Engineering Geology, vol. 271, Article ID 105597, 2020.

[43] Y. Zhang, G. Su, B. Liu, and T. Li, “A novel displacement back analysis method considering the displacement loss for underground rock mass engineering," Tunnelling and Underground Space Technology, vol. 95, Article ID 103141, 2020.

[44] L.-F. Contreras and E. T. Brown, "Slope reliability and back analysis of failure with geotechnical parameters estimated using bayesian inference," Journal of Rock Mechanics and Geotechnical Engineering, vol. 11, no. 3, pp. 628-643, 2019.

[45] D. G. Fredlund, N. R. Morgenstern, and R. A. Widger, "The shear strength of unsaturated soils," Canadian Geotechnical Journal, vol. 15, no. 3, pp. 313-321, 1978.

[46] H. Haeri, A. Khaloo, and M. F. Marji, "A coupled experimental and numerical simulation of rock slope joints behavior," Arabian Journal of Geosciences, vol. 8, no. 9, pp. 7297-7308, 2015.

[47] L. N. Y. Wong and Z. Wu, "Application of the numerical manifold method to model progressive failure in rock slopes," Engineering Fracture Mechanics, vol. 119, pp. 1-20, 2014.

[48] L. Zeng, L.-Y. Xiao, J.-H. Zhang, and Q.-F. Gao, "Effect of the characteristics of surface cracks on the transient saturated zones in colluvial soil slopes during rainfall," Bulletin of Engineering Geology and the Environment, vol. 79, no. 2, pp. 699-709, 2020. 